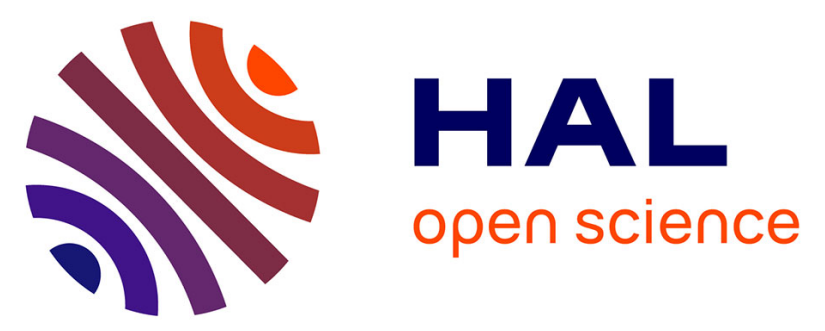

\title{
Biorefinery concept comprising acid hydrolysis, dark fermentation, and anaerobic digestion for co-processing of fruit and vegetable wastes and corn stover
}

\author{
Santiago Rodríguez-Valderrama, Carlos Escamilla-Alvarado, Pasiano \\ Rivas-García, Jean-Pierre Magnin, Mónica Alcalá-Rodríguez, Refugio \\ Bernardo García-Reyes
}

\section{To cite this version:}

Santiago Rodríguez-Valderrama, Carlos Escamilla-Alvarado, Pasiano Rivas-García, Jean-Pierre Magnin, Mónica Alcalá-Rodríguez, et al.. Biorefinery concept comprising acid hydrolysis, dark fermentation, and anaerobic digestion for co-processing of fruit and vegetable wastes and corn stover. Environmental Science and Pollution Research, 2020, 27 (23), pp.28585-28596. 10.1007/s11356-02008580-z . hal-02951145

\section{HAL Id: hal-02951145 \\ https://hal.univ-grenoble-alpes.fr/hal-02951145}

Submitted on 30 Nov 2020

HAL is a multi-disciplinary open access archive for the deposit and dissemination of scientific research documents, whether they are published or not. The documents may come from teaching and research institutions in France or abroad, or from public or private research centers.
L'archive ouverte pluridisciplinaire HAL, est destinée au dépôt et à la diffusion de documents scientifiques de niveau recherche, publiés ou non, émanant des établissements d'enseignement et de recherche français ou étrangers, des laboratoires publics ou privés. 


\title{
Biorefinery concept comprising acid hydrolysis, dark fermentation and anaerobic digestion for co-processing of fruit and vegetable wastes and corn stover
}

4 Santiago Rodríguez-Valderrama ${ }^{1}$, Carlos Escamilla-Alvarado ${ }^{1}$, Pasiano Rivas-García ${ }^{1}$, Jean-Pierre Magnin ${ }^{2}$, Mónica Alcalá-

\author{
Rodríguez $z^{3}$ Refugio Bernardo García-Reyes ${ }^{3}$
}

6

1 Universidad Autónoma de Nuevo León, Centro de Investigación en Biotecnología y Nanotecnología (CIByN), Facultad

8 de Ciencias Químicas, Engineering and Sustainable Bioprocesses Group, Parque de Investigación e Innovación

Tecnológica, km 10 Highway to International Airport Mariano Escobedo, 66629, Apodaca, Nuevo León, México

102 Univ. Grenoble Alpes, CNRS, Grenoble INP*, LEPMI, 38000 Grenoble, France * Institute of Engineering Univ.

Grenoble Alpes

123 Universidad Autónoma de Nuevo León, UANL, Facultad de Ciencias Químicas, Av. Universidad S/N, Ciudad Uniersitaria, San Nicolás de los Garza, N.L., 66455, Mexico

\section{4}

16 *Author for all correspondence: Carlos Escamilla Alvarado, ScDr.

18 Engineering and Sustainable Bioprocesses Group Centre for Research on Biotechnology and Nanotechnology (CIByN),

20 Faculty of Chemical Sciences

Universidad Autónoma de Nuevo León

22 Apodaca, Nuevo León, Mexico

Tel.: +528183294000

24 E-mail: cea_escamilla@yahoo.com.mx 


\section{Biorefinery concept comprising acid hydrolysis, dark fermentation and anaerobic digestion for co-processing of fruit and vegetable wastes and corn stover}

30 Abstract

A new biorefinery conceptual process is proposed for biohydrogen and biomethane production from a

32 combination of fruits and vegetables wastes (FVW) and corn stover (CS). The objective of this work was to perform the acid hydrolysis $\left(\mathrm{HCl} 0.5 \% \mathrm{v} / \mathrm{v}, 120{ }^{\circ} \mathrm{C}, 2 \mathrm{~h}\right.$ ) of the $\mathrm{FVW}$ and $\mathrm{CS}$ at 3:1 dry basis ratio, and

34 to process its main physical phases, liquid hydrolyzates (LH) and hydrolyzed solids (HS), by mesophilic dark fermentation (DF) and anaerobic digestion (AD), respectively. In DF of LH as carbon source,

36 hydrogen was produced at maximum rate of $2.6 \mathrm{~mL} \mathrm{H}_{2} /\left(\mathrm{g}_{\text {glucose }} \mathrm{h}\right)$ and maximum accumulation of 223.8 $\mathrm{mL} \mathrm{H}_{2} / \mathrm{g}_{\text {glucose }}$, equivalent to $2 \mathrm{~mol} \mathrm{H}_{2} / \mathrm{mol}_{\text {glucose }}$, in a butyric-pathway driven fermentation. HS were

38 digested to methane production assessing inoculum to substrate ratios in the range $2-4 \mathrm{~g}_{\text {inoculum }} / \mathrm{g}_{\mathrm{vs}}$. The main results in $\mathrm{AD}$ were, $14 \mathrm{mmol} \mathrm{CH} / \mathrm{g}_{\mathrm{vs}}$. The biorefinery demonstrated the feasibility to integrate the

40 acid hydrolysis as pretreatment and subsequently use the LH for hydrogen production, and the HS for methane production, with an energy yield recovery of $9.7 \mathrm{~kJ} / \mathrm{g}_{\mathrm{vs}}$, being the energy contribution from 42 anaerobic digestion 8-fold higher than of dark fermentation.

Keywords: Biohydrogen; Furfural; Hydrochloric acid; Lignocellulosic waste; Methane; Multisubstrate;

46 Phenolic compounds 


\section{Introduction}

50 Mexico is committed to reducing its greenhouse gases (GHG) by the year 2030 to $22 \%$, whereas emissions of short-lived climate pollutants (black carbon) are aimed to 51\% reduction (Gobierno de México 2015).

52 The main proposals for obtaining energy from renewable sources are bioenergy, solar energy, geothermal energy, hydroelectric energy, wind energy, and tidal energy. The biomass as a source for bioenergies, i.e.

54 biohydrogen, biomethane, bioethanol, and biobutanol (Mahlia et al. 2019), is most promising in the energetic share it could reach; according to some estimates, in Mexico it could supply ca. $46 \%$ of the

56 annual energy, yet currently, only 5\% is supplied (International Energy Agency 2016).

Residual biomass can be classified by its origin in forestry residues, agricultural residues, agro-

58 industrial wastes and organic fraction of municipal solid waste ( $\mathrm{Li}$ et al. 2016). Residual biomass exhaustive use has led to the development of the biorefinery of residues.

60 The biorefinery concept is associated with the intensive conversion of organic matter into added-value products (Escamilla-Alvarado et al. 2016; Moncada-Botero et al. 2016). Biorefineries are outlined by the

62 following sections: $i$ ) pretreatment section to fractionate biomass, ii) section of bioprocesses (e.g. fermentation, digestion), iii) purification of bioproducts to discard impurities and pollutants, and $i v$ ) energy

64 conversion section (Giuliano et al. 2016; Hernández-Flores et al. 2017).

The pretreatment with the highest efficiency of fermentable sugars release is diluted acid hydrolysis

66 (Gonzales et al. 2016; Joglekar et al. 2019). It employs high temperatures and acids in low concentrations to hydrolyze macromolecules such as cellulose and hemicellulose into monomeric sugars such as glucose,

68 xylose, arabinose, and others (Kumar et al. 2015). Such soluble hydrolyzate is prone to any kind of fermentation, yet the insoluble fraction remaining from the pretreatment (hydrolyzed solids) is also

70 susceptible for downstream processing. In the biorefinery perspective, the use of both hydrolyzates would be very attractive to increase the productivities of the installation. 
Fermentable sugars in liquid hydrolyzates (HL) can be used as a carbon source to produce hydrogen through dark fermentation (DF) bioprocess (Roy and Das 2016). On the other hand, the insoluble biomass,

74 or hydrolyzed solids (HS), may be converted into a bioenergetic such as methane through anaerobic digestion (AD) (Oliwit et al. 2019). Actually, only few works have dealt with the either DF or AD of

76 hydrolyzates with interesting results. For instance, Datar et al. (2007) applied steam explosion hydrolysis followed by the separated fermentation of the liquid hydrolyzates and the solid hydrolyzates for hydrogen

78 production. Curiously, the dark fermentation of solid hydrolyzates did not produce hydrogen during the first $21 \mathrm{~d}$, which was attained only after $20 \mathrm{~h}$ since the addition of cellulases. On the other hand, Tapia80 Rodríguez et al. (2019) evaluated the parallel production of hydrogen and methane from enzymatic hydrolyzates of agave bagasse, however the HS were not included in the biorefining process.

82 The sources of biomass for biorefineries are numerous and in order to not compromise the food supply, biowastes should be mainly used as its substrates (Romero-Cedillo et al. 2016). Considering that Mexico 84 was the $11^{\text {th }}$ agriculture producer worldwide with an annual production of 210 million tons in 2018 (SADER 2019), its wastes generation along the food supply chains (production, postharvest, processing,

86 distribution, consumption) are also considerable. Indeed, as corn is the second most important crop in Mexico, the wastes associated to the over $26 \times 10^{6}$ metric tons production (SADER 2019) are corn stover

88 (CS) and corn cobs. Since close to $82 \%$ of the CS generated is used for animal feed, the remaining $18 \%$ does not have a defined use (ca. $4.7 \times 10^{6}$ metric tons in dry base) and is therefore underused (Hernández 90 et al. 2019). Currently, CS is the most promising lignocellulosic waste for biofuels production due to its high cellulose (23-40\%) and hemicellulose (12-32\%) contents, and its low-cost abundant biomass (Kim 92 et al. 2019; Tan et al. 2019). 
Another underused biowaste in Mexico are the fruits and vegetable wastes (FVW), which compose $c a$.

$9444 \%$ of municipal solid wastes and that are disposed in landfills and open dumps (Taboada-González et al. 2011; Díaz et al. 2017; Gavilán et al. 2018).

96 Even though worldwide distribution of biowaste has raised attractiveness on biorefineries, some traits of these substrates such as its recalcitrant nature and seasonal availability are some of the most important 98 challenges for the development of biorefineries at large scale (Sultana and Kumar 2011; Giuliano et al. 2016). It has been proposed that the combination of multiple lignocellulosic biomass would be a feasible

100 solution as it also improves biofuels yields, complements the nutritional balance and reduces delivery costs (Sultana and Kumar 2011; Wang et al. 2011). Therefore, this work aimed to evaluate a biorefinery

102 concept for biohydrogen and biomethane production, as well as the resulting energy potential, from a combination of fruits and vegetables wastes (FVW) and corn stover (CS). The biorefinery concept $(h-H$ -

$104 M$ ) integrated the diluted acid hydrolysis $(h)$ as pretreatment and the parallel production of hydrogen by DF $(H)$ from liquid hydrolyzates and methane $(M)$ from hydrolyzed solids.

\section{Materials and methods}

\section{Biorefinery $h-H-M$ set up}

The FVW and CS were used as substrates to test the $h-H-M$ biorefinery concept as shown in Fig 1 . The 110 co-substrates were combined in dry basis $(\mathrm{db})$ at the ratio 3:1 FVW:CS according to RodríguezValderrama (2018). The co-substrates were subjected to hydrolysis pretreatment (h-stage) using $\mathrm{HCl}$ as

112 the catalyst acid. After the dilute acid hydrolysis, the liquid and solid phases were separated by centrifugation. Liquid hydrolysates (LH) were limed to decrease the concentration of inhibitory

114 compounds, and used as a carbon source in an $\mathrm{H}_{2}$-producing dark fermentation stage (H-stage) at mesophilic temperature. The hydrolyzed solids (HS) were washed to remove the catalyst acid excess and 
116 used as carbon source in a methane producing anaerobic digestion bioprocess ( $M$-stage). Each of the three stages will be described in detail in the following sections.

INSERT FIG. 1

\section{Co-substrates}

122 Corn stover (collected from Cuencamé, Durango, Mexico) and FVW (collected from a local cafeteria Chemical Sciences Faculty, Universidad Autónoma de Nuevo León, Nuevo León, Mexico) were 124 separately dried in an oven at $85{ }^{\circ} \mathrm{C}$ for $24 \mathrm{~h}$, grinded to $180 \mu \mathrm{m}$ particle size of using a manual mill, and stored in distinct tightly closed plastic bags at room temperature. FVW and CS were physico-chemically

126 characterized (Table 1). The empirical molecular formulas and the heat power value were $\mathrm{CH}_{4.31} \mathrm{O}_{0.68} \mathrm{~N}_{0.01}$, $3606 \mathrm{cal} / \mathrm{g}_{\mathrm{db}}$, and $\mathrm{CH}_{0.8} \mathrm{O}_{0.62} \mathrm{~N}_{0.04}, 2712 \mathrm{cal} / \mathrm{g}_{\mathrm{db}}$ for $\mathrm{CS}$ and $\mathrm{FVW}$, respectively.

INSERT TABLE 1

\section{Diluted acid hydrolysis and overliming}

The acid hydrolysis was carried out using dilute $\mathrm{HCl}(0.5 \% \mathrm{v} / \mathrm{v})$ in $0.5 \mathrm{~L}$ Schott bottles. The reaction 134 volume was $0.3 \mathrm{~L}$ and the solid content was $6.6 \%$ of reaction volume. The co-substrates ratio was 3:1 FVW:CS (g:g). The hydrolysis reaction was performed in an autoclave $\left(121^{\circ} \mathrm{C}\right)$ for $120 \mathrm{~min}($ Yan et al. 136 2009; Kumar et al. 2015). After the hydrolysis, liquid hydrolyzates (LH) were separated by centrifugation (10 $000 \mathrm{~g}, 10 \mathrm{~min})$ and characterized in terms of reducing and monomeric sugars and the inhibitory 
138 compounds, i.e. acetic acid, formic acid, furfural, 5- hydroxymethyl-furfural (HMF), and total phenolic compounds (TPC).

140 Overliming treatment was used applied to the LH in a two-step approach (Chang et al. 2011). Firstly, the $\mathrm{pH}$ of $\mathrm{LH}$ was adjusted to 10 by adding powder $\mathrm{Ca}(\mathrm{OH})_{2}$ in continuous stirring for one hour. Secondly,

142 the $\mathrm{pH}$ was reduced to to 7 by $6 \mathrm{M} \mathrm{HCl}$ addition, following a centrifugation $(10000 \mathrm{~g}, 15 \mathrm{~min})$ and the separation of liming precipitates and supernatant. Sample were retrieved from the LH to analyze the

144 removal of inhibitory compounds and sugars.

\section{Dark fermentation}

DF was carried out by duplicate in $0.5 \mathrm{~L}$ Schott bottles with $0.4 \mathrm{~L}$ of reaction volume. The methanogenic 148 anaerobic sludge was heat-treated to inhibit methane-producing microflora in water bath at $96^{\circ} \mathrm{C}$ for $2 \mathrm{~h}$. The initial reducing sugars (RS) were adjusted to $13 \mathrm{~g} / \mathrm{L}$ and the amount of substrate and inoculum were 150 added according to the inoculum to substrate ratio (ISR) of 1.2 (VS basis). The fermentation volume was supplemented with $4 \mathrm{~mL}$ of 200 fold mineral medium previously reported by Rodríguez-Valderrama et

152 al. (2019). The medium was supplemented with nitrogen source $\left(1 \mathrm{~g} \mathrm{NH}_{4} \mathrm{Cl} / \mathrm{L}\right)$ and buffer medium $(3 \mathrm{~g}$ $\mathrm{K}_{2} \mathrm{HPO}_{4} / \mathrm{L}, 1.5 \mathrm{~g} \mathrm{KH}_{2} \mathrm{PO}_{4} / \mathrm{L}$ ). The experimental units were stirred at $150 \mathrm{rpm}$ in a multiple magnetic stirrer 154 inside an incubator at $35^{\circ} \mathrm{C}$.

156 Anaerobic digestion

HS from the separation of LH were washed twice with distilled water ( $0.03 \mathrm{~L}$ of water per $10 \mathrm{~g}_{\mathrm{wb}}$ of HS), 158 vortexed and sedimented for $10 \mathrm{~min}$, to remove the residual acid catalyst. Afterwards, HS were recovered 
by centrifugation $(15 \mathrm{~min}$ at $10000 \mathrm{~g})$, dried at $80^{\circ} \mathrm{C}$ and characterized (Table 1). HS empirical molecular

160 formula based on elemental composition was $\mathrm{CH}_{2.30} \mathrm{O}_{0.42} \mathrm{~N}_{0.03}$.

AD was carried out in $0.120 \mathrm{~L}$ serum bottles with $0.08 \mathrm{~L}$ of work volume. The inoculum was anaerobic

162 sludge from a semi-continuous digester fed with FVW at $30 \mathrm{~d}$ of hydraulic retention time. The inoculum was degassed during $3 \mathrm{~d}$ and then used for HS anaerobic digestion. The inoculum had the following

164 characteristics: $7.81 \mathrm{pH}, 93.64 \%_{\mathrm{wb}}$ moisture, $6.36 \%_{\mathrm{wb}} \mathrm{TS}, 51.46 \%_{\mathrm{db}} \mathrm{VS}, 48.54 \%_{\mathrm{db}}$ ashes. The alkalinity and total VFA were $12300 \mathrm{mg} \mathrm{CaCO}_{3} / \mathrm{L}$ and $8040 \mathrm{mg} \mathrm{VFA} / \mathrm{L}$, respectively. Its empirical molecular

166 formula based on elemental composition was $\mathrm{CH}_{1.34} \mathrm{O}_{2.02} \mathrm{~N}_{0.10}$.

Inoculum to substrate ratios (ISR) were assayed in batch mode: $2,2.5,3,3.5$ and $4 \mathrm{~g}_{\mathrm{vs}}$ inoculum/ $\mathrm{g}_{\mathrm{vs}}$

168 HS. A control was run with fresh FVW at ISR 3. A blank was loaded only with inoculum and water to to determine the methane production by the organic matter present in the inoculum. The methane production

$170\left(2.16 \mathrm{mmol} \mathrm{CH}_{4}\right)$ from blanks was subtracted from the methane produced by HS. All the experimental units were kept constant in its inoculum content at $2.5 \mathrm{~g}_{\mathrm{vs}}$, the substrate amounts were adjusted according

172 to each ISR. The anoxic environment in each bottle was promoted by flushing $\mathrm{N}_{2}$ during $3 \mathrm{~min}$. Afterwards, the bottles were sealed with a rubber stopper and aluminum rings. The operation temperature

174 and stirred velocity were $35 \pm 1{ }^{\circ} \mathrm{C}$ and $150 \mathrm{rpm}$, respectively. All the experiments were carried out by duplicate.

\section{Analytical methods}

178 The $\mathrm{pH}$ was determined according to the procedure described by NMX-AA-25-1984 (1992). Solids profile was measured according to standard methods (APHA/AWWA/WEF 2005). Cellulose and acid-insoluble

180 lignin contents were determined by the gravimetric method base on AOAC methods (AOAC 1992). Hemicellulose amount was determined subtracting the cellulose content from holocellulose content after 
182 by lignin oxidation by $\mathrm{NaClO}$ (Escamilla-Alvarado et al. 2015). The extractives in CS and FVW were determined by differential weight after extraction in a water bath at $60{ }^{\circ} \mathrm{C} 24 \mathrm{~h}$ (Sluiter et al. 2008). The

184 elemental characterization $(\mathrm{C}, \mathrm{H}, \mathrm{O}, \mathrm{N})$ was determined by an elemental analyzer (Thermo Scientific Flash 2000, U.S.A), $\mathrm{O}_{2}$ was used as combustion gas and $\mathrm{He}$ was used as carrier gas.

186 The reducing sugars (RS) in hydrolyzate were determined by the 3,5-dinitrosalicylicacid method (DNS) using dextrose for the calibration curve (Miller 1959). Glucose, xylose, and arabinose were quantified by

188 high performance liquid chromatograph (LDC Analytical, U.S.A.) equipped with a Rezex RHMMonosaccharide (300mm X $7.8 \mathrm{~mm}$ ) column and a refractive index detector (Varian Prostar, U.S.A.). The 190 column temperature was $65^{\circ} \mathrm{C}$, whereas the mobile phase $\left(\mathrm{H}_{2} \mathrm{O}\right)$ flow rate was maintained at $0.6 \mathrm{~mL} / \mathrm{min}$.

The total amount of biogas produced in $\mathrm{DF}$ and $\mathrm{AD}$ was determined by the acid-brine displacement 192 method (Escamilla-Alvarado et al. 2013). Hydrogen and methane gas contents were determined in a gas chromatograph (Thermo Scientific Trace 1310, U.S.A.); the gas chromatograph was equipped with a 194 thermal conductivity detector and a molecular sieve column (TG-BOND Msieve 5A, $30 \mathrm{~m}$ x $0.33 \mathrm{~mm}$ ). The operating temperatures were $100{ }^{\circ} \mathrm{C}, 150{ }^{\circ} \mathrm{C}$, and $200^{\circ} \mathrm{C}$ for the oven, injector, and detector, 196 respectively. Nitrogen gas was used as a carrier gas with a flow rate of $3 \mathrm{~mL} / \mathrm{min}$.

The total phenolic compounds (TPC) were determined by the Folin-Ciocalteu method proposed by 198 Blainski et al. (2013) using tannic acid as the standard. Furfural, HMF, formic acid, acetic acid, propionic acid, succinic acid, and lactic acid were demined by gas chromatography (Varian CP 3380, U.S.A.) with 200 a column ZB-FFAP $(15 \mathrm{~m} \times 0.53 \times 1 \mu \mathrm{m})$ and flame ionization detector. The injector and detector temperatures were 230 and $280{ }^{\circ} \mathrm{C}$, respectively. The temperature program for the column initiated at 90 $202{ }^{\circ} \mathrm{C}$ for $3 \mathrm{~min}$, then increased to $200{ }^{\circ} \mathrm{C}$ at $20^{\circ} \mathrm{C} / \mathrm{min}$ rate and maintained for $3 \mathrm{~min}$, and finally raised to $250{ }^{\circ} \mathrm{C}$ at $30{ }^{\circ} \mathrm{C} / \mathrm{min}$, which was maintained for $4 \mathrm{~min}$. 
Total volatile fatty acids (TVFA) and alkalinity concentration were determined by a titration method (Anderson and Yang 1992). Acetic acid, propionic acid, butyric acid, and ethanol were quantified using a gas chromatograph according to the method described in our previous work (Rodríguez-Valderrama et al. 2019).

\section{Calculations}

210 A set of response variables was calculated according to Table 2 to analyze the production of hydrogen, methane and energy potential. The cumulative specific hydrogen production $H(t)\left(\mathrm{mL} \mathrm{H}_{2} / \mathrm{g}_{\text {glucose }}\right)$ was used

212 for describing the accumulated production of hydrogen in time and to obtain kinetic parameters from fitting the results by the Gompertz equation (Eq. 1). Thus, the maximum cumulative specific hydrogen

214 production $H_{\max }\left(\mathrm{mL} \mathrm{H}_{2} / \mathrm{g}_{\mathrm{glucose}}\right)$, the maximum specific hydrogen production rate $r_{\max , H}\left(\mathrm{~mL} \mathrm{H}_{2} /\left(\mathrm{g}_{\mathrm{glucose}}\right.\right.$ h)) and the adaptation time $\lambda(\mathrm{h})$ were determined.

216 The hydrogen molar pseudoyield, $Y^{\prime}{ }{ }_{2}\left(\mathrm{~mol} \mathrm{H}_{2} / \mathrm{mol}_{\text {glucose }}\right)$ in Eq. 2 was obtained from the $H_{\max }(\mathrm{mL}$ $\mathrm{H}_{2} / \mathrm{g}_{\text {glucose }}$ ) as a means to compare the system to the maximum theoretical hydrogen yield ( 2 and $4 \mathrm{~mol}$

$218 \mathrm{H}_{2} / \mathrm{g}_{\text {glucose }}$ for butyrogenic and acetogenic pathways, respectively).

Other variables in the equations listed in Table 2 used in Eq. 1 or Eq. 2 are $t$ is fermentation time (h), $e$ is

2.718, $C_{R S, 0}$ and $C_{R S, f}(\mathrm{~g} / \mathrm{L})$ are the concentration of RS at the beginning and at the end of DF, and $M W_{\text {glucose }}$ is the glucose molar weight $(180.16 \mathrm{~g} / \mathrm{mol})$.

Regarding the AD equations and parameters (Table 2), the cumulative methane production $B(t)$ (mmol $\left.\mathrm{CH}_{4}\right)$ and cumulative specific methane production $b(t)\left(\mathrm{mmol} \mathrm{CH}_{4} / \mathrm{g}_{\mathrm{vs}}\right)$ were used to calculate the kinetic 224 parameters by two methods: an adaptation of the Gompertz equation (Lo et al. 2010, Eq. 3 and Eq. 4), and the first-order model proposed by Hashimoto (1989, Eq. 5 and Eq. 6). Through Eq. 3 and Eq. 5 the 226 maximum cumulative methane production $B_{\max }$ is obtained, whereas through Eq. 4 and 6 the maximum 
cumulative specific methane production $b_{\max }$ is estimated. The other parameters estimated through these

228 equations are the maximum methane production rate $R_{\max , M}\left(\mathrm{mmol} \mathrm{CH}_{4} / \mathrm{d}\right)$, the maximum specific methane production rate $r_{\max , M}\left(\mathrm{mmol} \mathrm{CH}_{4} /\left(\mathrm{g}_{\mathrm{vs}} \mathrm{d}\right)\right), \lambda$, and the methane production rate $k(1 / \mathrm{d})$.

230 The specific gross energy potential $\hat{E}_{p}\left(\mathrm{~kJ} / \mathrm{g}_{\mathrm{vs}}\right)$ was used to compare our $h-H-M$ biorefinery against other biorefinery models in the literature, either serial where $\mathrm{DF}$ is followed by $\mathrm{AD}$ (Eq. 7), or in parallel

$232 \mathrm{DF}$ and $\mathrm{AD}$ systems (Eq. 8). In these equation, the hydrogen high heating value $H H V_{H 2}$ is $282.8 \mathrm{~kJ} / \mathrm{mol}$, the methane high heating value $H H V_{C H 4}$ is $889.9 \mathrm{~kJ} / \mathrm{mol}, V_{M}$ is the molar volume of an ideal gas at standard 234 conditions (22.4 L/mol), 1000 is the $\mathrm{mL}$ to $\mathrm{L}$ conversion factor, $\eta_{\mathrm{DF}}$ is the quotient of VS consumed and VS fed in the DF units, and $\eta_{\mathrm{AH}}$ is the quotient of glucose released and VS fed in acid hydrolysis 236 experiments.

238 INSERT TABLE 2

240 Results and Discussion

Diluted acid hydrolysis and overliming

242 The RS concentration after co-substrates hydrolysis was $23.49 \mathrm{~g} / \mathrm{L}$, containing high amounts of glucose $(10.36 \mathrm{~g} / \mathrm{L})$ followed by xylose $(8.61 \mathrm{~g} / \mathrm{L})$ and arabinose $(0.39 \mathrm{~g} / \mathrm{L})$. The RS production yield was $48.54 \%$

244 (calculated as the amount of RS produced divided by the sum of volatile solids added) for the 3:1 FVW:CS combination. This yield is comparable to those reported in the literature for acid hydrolysis of either FVW

246 or CS. For instance, Datar et al. (2007) obtained a hydrolysis yield of $47 \%$ in the steam-explosion treatment of acid impregnated CS. Cao et al. (2009) managed to extract the $35.20 \%$ of sugars in the CS 248 acid hydrolysis. On the other hand, Díaz et al. (2017) extracted $35.9 \%$ of the reducing sugars available in tomato wastes through acid hydrolysis. Additionally, one of the main benefits of the co-substrates acid 
250 hydrolysis is the improvement of the monomeric sugars distribution. For instance, in our 3:1 FVW:CS experiment the monosaccharide distribution in the liquid hydrolyzates was $53.5 \%$ glucose, $44.5 \%$ xylose

252 and $2 \%$ arabinose (Table 1). In contrast, the main monomeric sugars distribution from hydrolysis of only CS were $9.08 \%$ of glucose, $83.08 \%$ of xylose and $7.84 \%$ of arabinose (Datar et al. 2007), whereas FVW 254 were only composed of $100 \%$ hexoses (Del Campo et al. 2006).

The overliming treatment of acid hydrolyzates successfully reduced the inhibitory compounds as TPC 256 in 33.86\%, although $10.05 \%$ RS were also lost (Table 3). RS loss is commonly expected in such treatments (Saha et al. 2005), for instance, Chang et al. (2011) reported 9\% RS loss after the overliming of rice husk 258 hydrolyzates, and Purwadi et al. (2004) had 8.42\% RS loss from detoxification by $\mathrm{Ca}(\mathrm{OH})_{2}$ of Swedish forestry residues hydrolyzates. The concentration of TPC, HMF, furfural, and acetic acid, did not surpass 260 the concentrations known to inhibit hydrogen production, which are in the following ranges: $0.8-2.28 \mathrm{~g} / \mathrm{L}$ for TPC, $0.86-1.89 \mathrm{~g} / \mathrm{L}$ for HMF, $0.8-3.41 \mathrm{~g} / \mathrm{L}$ for furfural and 0.6-7.80g/L for acetic acid (Ren et al. 2008;

262 Gonzales et al. 2016).

264 INSERT TABLE 3

\section{Darkfermentation}

After overliming pretreatment, the $\mathrm{LH}$ were used for hydrogen production at initial $\mathrm{pH}$ of 7 and $35^{\circ} \mathrm{C}$.

268 After $150 \mathrm{~h}$ of fermentation, maximum experimental cumulative biogas and maximum cumulative specific hydrogen production were $2717 \mathrm{~mL}$ and $223.8 \mathrm{~mL} \mathrm{H}_{2} / \mathrm{g}_{\text {glucose }}$, respectively (Fig. 2). The hydrogen average 270 content in biogas was 50.89\%, whereas methane was not detected. According to the Gompertz parameters

(Table 4), the production of hydrogen from the acid hydrolyzates of the co-substrates mixtures (3:1 272 FVW:CS) showed a $r_{\max , H}$ of $2.60\left(\mathrm{~mL} \mathrm{H}_{2} /\left(\mathrm{g}_{\text {glucose }} \mathrm{h}\right)\right)$ and $19.25 \mathrm{~h}$ of adaptation time. 
$r_{\max , H}$ is comparable to other studies presented in literature where hydrogen production from acidic

274 hydrolyzates of organic waste has been studied. Zhang et al. (2015) reported a $r_{\max , H}$ of $0.92(\mathrm{~mL}$ $\left.\mathrm{H}_{2} /\left(\mathrm{g}_{\text {glucose }} \mathrm{h}\right)\right)$ in a $100 \mathrm{~mL}$ serum vials with acid hydrolyzates $\left(1.7 \% \mathrm{v} / \mathrm{v} \mathrm{H}_{2} \mathrm{SO}_{4}, 120 \mathrm{~min}, 120{ }^{\circ} \mathrm{C}\right)$ from

276 CS produced by activated sludge. The reason for their low $r_{\max , H}$ compared to our study might be attributed to the low initial sugars concentration $(5 \mathrm{~g} / \mathrm{L}$ against $13 \mathrm{~g} / \mathrm{L}$, respectively) and the low initial ISR (0.19

278 against 1.2, respectively), as such parameters are directly related to hydrogenogenic performance (Fan et al. 2006; Ozmihci et al. 2011). In addition, the hydrogen batch fermentation at ISR lower than 0.16 could 280 have presented inhibition due to the high amounts of substrate (Wong et al. 2014).

282 INSERT FIG. 2

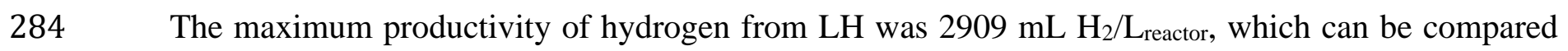
with other studies also using LH for hydrogen production. In the case of Datar et al. (2007), they reported 286 hydrogen productivity of $3310 \mathrm{~mL} \mathrm{H}_{2} / \mathrm{L}_{\text {reactor }}$ from CS hydrolyzates in a CSTR reactor using a pre-treated anaerobic sludge as an inoculum; the volumetric productivity reported in our work was $12.1 \%$ lower than 288 theirs. However, the adaptation time reported by Datar et al. (2007) was $49.5 \%$ higher due to the initial concentrations of inhibitors present in their hydrolyzates.

INSERT TABLE 4

The molar pseudoyield obtained at $35^{\circ} \mathrm{C}$ was $2.02 \mathrm{~mol} \mathrm{H}_{2} / \mathrm{mol}_{\text {glucose }}$, comparable to those using pure 294 and mixed cultures from acid hydrolyzates. Biohydrogen production from starch hydrolyzates led to a maximum $Y_{H_{2}}$ of 1.28 and $0.85 \mathrm{~mol} \mathrm{H}_{2} / \mathrm{mol}_{\text {glucose }}$ by either Clostridium pasteurianum $\mathrm{CH} 5$ or by 
296 consortium from dark fermentation sludge, respectively (Chen et al. 2008). Both experiments were carried out at $37{ }^{\circ} \mathrm{C}$ and initial sugars concentration of $26.7 \mathrm{~g} / \mathrm{L}$. Using acid hydrolyzates from wheat starch $(121$

$298{ }^{\circ} \mathrm{C}, 15 \mathrm{~min}, \mathrm{pH} 2.5, \mathrm{H}_{2} \mathrm{SO}_{4}$ ), Cakr et al. (2010) obtained a $\mathrm{Y}^{\prime}{ }_{\mathrm{H} 2}$ of $2.4 \mathrm{~mol} \mathrm{H}_{2} /$ molglucose at $55^{\circ} \mathrm{C}$ and initial sugars concentration of $18.5 \mathrm{~g} / \mathrm{L}$ using heat-treated anaerobic sludge. This value was 1.2 -fold higher than

300 ours, however, the use of thermophilic temperatures may decrease the energy gains from biofuels production (Rodríguez-Valderrama et al. 2019).

302 The final $\mathrm{pH}$ in hydrogen production was 5.34 (Table 4), an adequate value for hydrogen production as reported in literature (Braguglia et al. 2018). In our experiments, the $\mathrm{pH}_{0}$ was adjusted to 7 304 as commonly done in free fermentation experiments. For instance, Liu et al. (2013) observed a considerable hydrogen yield increase from $0.02 \mathrm{~mol} \mathrm{H}_{2} / \mathrm{mol}_{\text {sugars }}$ at $\mathrm{pH}_{0} 5$, to $0.44 \mathrm{~mol} \mathrm{H}_{2} / \mathrm{mol}_{\text {sugars }}$ at $\mathrm{pH}_{0}$ 3067 when using rice straw acid hydrolyzates.

The main metabolites in DF were butyric acid $(6.13 \mathrm{~g} / \mathrm{L})$, acetic acid $(1.11 \mathrm{~g} / \mathrm{L})$, propionic acid $308(0.36 \mathrm{~g} / \mathrm{L})$ and a small amount of ethanol $(0.07 \mathrm{~g} / \mathrm{L})$, which indicates that the fermentation was carried out in greatly by butyric acid metabolic pathway (Chen et al. 2006; Wang and Wan 2009). These results 310 demonstrated the good performance of dark fermentation from acid hydrolyzates obtained from organic substrates mixtures by anaerobic sludge.

Anaerobic digestion

314 The cumulative methane production and specific methane production as a function of time for different ISR are shown in Fig 3. The best results for each parameter were obtained at ISR 2.5 and 4, respectively.

316 Indeed, all the experiments evaluated with HS presented methane productions and specific methane productions higher than the experiments with FVW (control) during the first five days due to the readily 
318 biodegradable organic matter in the HS. Still, at the end the control produced as good results as most of them due to the RIS used and the good biodegradability of FVW at high digestion times (Li et al. 2011).

320 The cumulative methane production $\left(B_{\max }\right)$ at the different studied ISR (2-4) was in the range 6.37 to 8.78 mmol $\mathrm{CH}_{4}$. The best results were obtained in the order ISR 2.5>4>3>2>3.5 (Table 5, Fig 3A). On the

322 other hand, the cumulative specific methane production $\left(b_{\max }\right)$ was in the range $5.84-13.64 \mathrm{mmol} \mathrm{CH} 4 / \mathrm{g}_{\mathrm{vs}}$, obtained from highest to lowest in the order ISR $4>3>3.5>2.5>2$. This was in agreement to reports in

324 literature that have ascribed this phenomenon to the fact that a greater inoculum to substrate ratio allows a more exhaustive conversion of biomass into methane (Hashimoto 1989).

326 The predicted maximum cumulative methane production $\left(B_{\max }, 8.90 \mathrm{mmol} \mathrm{CH}_{4}\right)$ and the lowest deviation in respect to the experimental value (1.30\%) were presented with the first-order kinetic model 328 for ISR=2.5, whereas Gompertz prediction had a deviation of $3.36 \%$ respect to the measured production. The coefficient of determination for this experiment $($ ISR $=2.5$ ) was 0.99 , slightly higher than the obtained 330 by the Gompertz model (0.99). The maximum methane rates $(k)$ for each ISR evaluated were in the range of 0.19 to $0.28(1 / \mathrm{d})$. The maximum $k(0.281 / \mathrm{d})$ corresponded to ISR of 2.5 , which could have reflected 332 a positive interaction of a rapid substrate biodegradability due to pretreatment and an adequate inoculum load. Similarly, at 2.5 ISR Moset et al. (2015) registered a $k$ of $0.16(1 / \mathrm{d})$ in the anaerobic digestion of 334 corn stover silage (1 year), and 0.08 (1/d) for wheat straw without any previous treatment.

The predicted specific methane productions $\left(b_{\max }\right)$ by the first-order kinetic and Gompertz models 336 were $14 \mathrm{mmol} \mathrm{CH}_{4} / \mathrm{g}_{\mathrm{vs}}$ and $13.2 \mathrm{mmol} \mathrm{CH} 4 / \mathrm{g}_{\mathrm{vs}}$, respectively (Table 6). However, the first-order kinetic model presented the best fit to the experimental data since its error (2.62\%) was lower than the respective 338 of the Gompertz model (3.07\%). These errors are usual when comparing the fits of mathematical models. As reported by Zhang et al. (2014) who obtained deviations from $1.5 \%$ for the first-order kinetic model 
340 and $3.7 \%$ for the Gompertz model when they evaluated the anaerobic digestion of dewatered sewage sludge at ISR of 1 and $37^{\circ} \mathrm{C}$ of fermentation temperature.

INSERT FIG. 3

\section{INSERT TABLE 5}

The maximum predicted $b_{\max }\left(14 \mathrm{mmol} \mathrm{CH} 4 / \mathrm{g}_{\mathrm{vs}}\right.$ or $\left.342.3 \mathrm{~L} \mathrm{CH} / \mathrm{kg}_{\mathrm{vs}}\right)$ is comparable to the maximum

348 methane specific productions in literature, only $8 \%$ lower than the value of $372.4 \mathrm{~L} \mathrm{CH}_{4} / \mathrm{kg}_{\mathrm{vs}}$, from alkaline pretreated (5\% $\mathrm{NaOH}) \mathrm{CS}$ on solid-state (Zhu et al. (2010). This difference may be mainly due

350 to the positive traits of alkaline treatment and its less severity compared to acid treatments. Besides lignin solubilization, alkaline pretreatments also provide neutralization of the different acids in lignocellulosic

352 compounds degradation. However, the maximum methane production rate $\left(9.3 \mathrm{~L} \mathrm{CH}_{4} /\left(\mathrm{kg}_{\mathrm{vs}} \mathrm{d}\right)\right)$ found by Zhu et al. (2010) after $40 \mathrm{~d}$, was 6.2 fold lower than that obtained from HS during $15 \mathrm{~d}(2.35 \mathrm{mmol}$

$\left.354 \mathrm{CH}_{4} /\left(\mathrm{g}_{\mathrm{vs}} \mathrm{d}\right) ; 57.4 \mathrm{~L} \mathrm{CH}_{4} /\left(\mathrm{kg}_{\mathrm{vs}} \mathrm{d}\right)\right)$, which indicates the rapid substrate degradation due to the acid pretreatment process.

356 The $b_{\max }$ and the $r_{\max , M}$ obtained in the control experiment with fresh untreated FVW were $10.01 \mathrm{mmol}$ $\mathrm{CH}_{4} / \mathrm{g}_{\mathrm{vs}}\left(244.5 \mathrm{~L} \mathrm{CH}_{4} / \mathrm{kg}_{\mathrm{vs}}\right)$ and $1.29 \mathrm{mmol} \mathrm{CH} 4 /\left(\mathrm{g}_{\mathrm{vs}} \mathrm{d}\right)\left(31.6 \mathrm{~L} \mathrm{CH}_{4} /\left(\mathrm{kg}_{\mathrm{vs}} \mathrm{d}\right)\right)$, respectively. This $b_{\max }$ was

$35828.63 \%$ lower than that obtained with $\mathrm{HS}\left(342.3 \mathrm{~L} \mathrm{CH}_{4} / \mathrm{kg}_{\mathrm{vs}}\right)$, because when pretreating a substrate, either by alkaline pretreatment or acidic pretreatment, the methane production is raised, since soluble organic 360 matter was increased and then easily used by microorganisms (Abudi et al. 2016). The increase in methane production $(28.63 \%)$ due to substrate pretreatment was also observed in the literature. For instance, Abudi 362 et al. (2016) registered the increment of $6.69 \%$ in the methane production from rice straw without 
pretreatment and $45.15 \%$ from alkali rice straw organic fraction of municipal solid wastes (OFMSW). On

364 the other hand, both substrates (rice straw and pretreated rice straw) showed higher methane production when compared to OFMSW digestion, but this phenomenon seems to be related to the nature of the 366 substrate rather than to the pretreatment applied.

\section{INSERT TABLE 6}

\section{Energy evaluation of the $h-H-M$ concept biorefinery}

The energy yield from $h-H-M$ biorefinery model and its comparison with two-stage systems from different

372 biomasses as substrates are shown in Table 7. The energy yield for $h-H-M$ biorefinery based on gaseous biofuels production was $9.7 \mathrm{~kJ} / \mathrm{g}_{\mathrm{vs}}$. The stage with the greatest contribution to the energy yield was the

374 methane production $(M)$ stage with a contribution near to $89.4 \%\left(8.7 \mathrm{~kJ} / \mathrm{g}_{\mathrm{vs}}\right)$, whereas the contribution of hydrogen produced in dark fermentation $(H)$ was the remaining $10.6 \%\left(1.0 \mathrm{~kJ} / \mathrm{g}_{\mathrm{vs}}\right)$. Ghimire et al. (2015)

376 calculated a maximum energy yield of $4.4 \mathrm{~kJ} / \mathrm{g}_{\mathrm{vs}}$ for hydrogen and methane production from food waste. Energy contribution of DF was $29.6 \%\left(1.3 \mathrm{~kJ} / \mathrm{g}_{\mathrm{vs}}\right)$ when the food wastes were fermented in a $1.5 \mathrm{~L}$ semi378 continuous reactor at $55^{\circ} \mathrm{C}$, whereas the maximum energy yield contribution was presented by $\mathrm{AD}(70.4 \%$, $\left.3.1 \mathrm{~kJ} / \mathrm{g}_{\mathrm{vs}}\right)$. The relatively low energy contribution of DF is ascribed to the inherent energy loss in the form 380 of metabolites in the effluents (Xia et al. 2013).

\section{INSERT TABLE 7}

\section{Conclusions}

384 This work demonstrated that a new biorefinery approach coined as $h-H-M$, was technically feasible for treating a preparation of fruits and vegetables wastes and corn stover through acid hydrolysis, dark 
386 fermentation and anaerobic digestion. Acid hydrolysis of the preparation 3:1 fruit and vegetable wastes to corn stover produced hydrolyzates containing up to $10.4 \mathrm{~g} / \mathrm{L}$ of glucose, $8.61 \mathrm{~g} / \mathrm{L}$ of xylose and $0.39 \mathrm{~g} / \mathrm{L}$ 388 of arabinose.

Dark fermentation from liquid hydrolyzates performed competitively at inoculum to substrate ratio 1.2, 390 reaching productivity of $2909.7 \mathrm{~mL} \mathrm{H}_{2} / \mathrm{L}_{\text {reactor }}$ and pseudoyield $2.02 \mathrm{~mol} \mathrm{H}_{2} / \mathrm{mol}_{\text {glucose. }}$.

The hydrolyzed solids were adequately used as carbon source for anaerobic digestion, promoting higher

392 initial methane production when compared to compared to fresh substrate. The maximum cumulative methane production, $8.9 \mathrm{mmol} \mathrm{CH}_{4}$, and the highest methane specific production, $13.6 \mathrm{mmol} \mathrm{CH} / \mathrm{g}_{\mathrm{vs}}$, 394 were obtained at the inoculum to substrate ratios of 2.5 and 4 , respectively.

The total energy potential from the $h-H-M$ biorefinery concept in the form of hydrogen and methane 396 reached $9.7 \mathrm{~kJ} / \mathrm{g}_{\mathrm{vs}}$, of which hydrogen contributed to $10.6 \%$.

Using a combination of co-substrates such as FVW and CS opens up the possibility of interesting 398 configurations for real biorefineries, as this approach may provide an alternative to mono-substrate drawbacks.

\section{Acknowledgments}

402 The authors express their gratitude to the Directive Board of the Chemical Sciences Faculty of the Universidad Autónoma de Nuevo León for supporting the project (02-106534-PST-15/123). Santiago

404 Rodríguez-Valderrama thanks Consejo Nacional de Ciencia y Tecnología (Conacyt) for the Scholarship No. 714579.

\section{References}

408 Abudi ZN, Hu Z, Sun N, Xiao B, Rajaa N, Liu C, Guo D (2016) Batch anaerobic co-digestion of OFMSW (organic fraction of municipal solid waste), TWAS (thickened waste activated sludge) and RS (rice straw):

Influence of TWAS and RS pretreatment and mixing ratio. Energy 107:131-140. doi: 
10.1016/j.energy.2016.03.141

412 Anderson GK, Yang G (1992) Determination of bicarbonate and total volatile acid concentration in anaerobic digesters using a simple titration. Water Environ Res 64:53-59. doi: 10.2175/WER.64.1.8

414 AOAC (1992) AOAC Official Methods of Analysis. Assoc Off Agric Chem Washington, DC

APHA/AWWA/WEF (2005) Standard Methods for the Examination of Water and Wastewater. Am Public Heal Assoc. doi: ISBN 9780875532356

Blainski A, Lopes GC, Palazzo de Mello JC (2013) Application and analysis of the Folin Ciocalteu method for the determination of the total phenolic content from Limonium Brasiliense L. Molecules 18:6852-6865. doi: $10.3390 /$ molecules 18066852

420 Braguglia CM, Gallipoli A, Gianico A, Pagliaccia P (2018) Anaerobic bioconversion of food waste into energy: A critical review. Bioresour Technol 248:37-56. doi: 10.1016/j.biortech.2017.06.145

422 Cakr A, Ozmihci S, Kargi F (2010) Comparison of bio-hydrogen production from hydrolyzed wheat starch by mesophilic and thermophilic dark fermentation. Int J Hydrogen Energy 35:13214-13218. doi: 10.1016/j.ijhydene.2010.09.029

Cao G, Ren N, Wang A, Lee DJ, Guo W, Liu B, Feng Y, Zhao Q (2009) Acid hydrolysis of corn stover for biohydrogen production using Thermoanaerobacterium thermosaccharolyticum W16. Int J Hydrogen Energy 34:7182-7188. doi: 10.1016/j.ijhydene.2009.07.009

Chang ACC, Tu YH, Huang MH, Lay CH, Lin CY (2011) Hydrogen production by the anaerobic fermentation from acid hydrolyzed rice straw hydrolysate. Int J Hydrogen Energy 36:14280-14288. doi: 10.1016/j.ijhydene.2011.04.142

Chen S-D, Lee K-S, Lo Y-C, Chen W-M, Wu J-F, Lin C-Y, Chang J-S (2008) Batch and continuous biohydrogen production from starch hydrolysate by Clostridium species. Int J Hydrogen Energy 33:1803-1812. doi: 10.1016/j.ijhydene.2008.01.028

Chen X, Sun Y, Xiu Z, Li X, Zhang D (2006) Stoichiometric analysis of biological hydrogen production by fermentative bacteria. Int J Hydrogen Energy 31:539-549. doi: 10.1016/j.ijhydene.2005.03.013

Datar R, Huang J, Maness PC, Mohagheghi A, Czernik S, Chornet E (2007) Hydrogen production from the fermentation of corn stover biomass pretreated with a steam-explosion process. Int J Hydrogen Energy 32:932-939. doi: 10.1016/j.ijhydene.2006.09.027

Del Campo I, Alegría I, Zazpe M, Echeverría M, Echeverría I (2006) Diluted acid hydrolysis pretreatment of agrifood wastes for bioethanol production. Ind Crops Prod 24:214-221. doi: 10.1016/j.indcrop.2006.06.014

Díaz AI, Laca A, Laca A, Díaz M (2017) Treatment of supermarket vegetable wastes to be used as alternative substrates in bioprocesses. Waste Manag 67:59-66. doi: 10.1016/j.wasman.2017.05.018

Escamilla-Alvarado C, Poggi-Varaldo HM, Ponce-Noyola MT (2016) Bioenergy and bioproducts from municipal organic waste as alternative to landfilling: a comparative life cycle assessment with prospective application to Mexico. Environ Sci Pollut Res 24:25602-25617. doi: 10.1007/s11356-016-6939-z

Escamilla-Alvarado C, Poggi-Varaldo HM, Ponce-Noyola T, Ríos-Leal E, Robles-Gonzalez I, RinderknechtSeijas N (2015) Saccharification of fermented residues as integral part in a conceptual hydrogen-producing biorefinery. Int J Hydrogen Energy 40:17200-17211. doi: 10.1016/j.ijhydene.2015.06.164

Escamilla-Alvarado C, Ponce-Noyola MT, Poggi-Varaldo HM, Ríos-Leal E, García-Mena J, Rinderknecht-Seijas $\mathrm{N}$ (2014) Energy analysis of in-series biohydrogen and methane production from organic wastes. Int $\mathrm{J}$ Hydrogen Energy 39:16587-16594. doi: 10.1016/j.ijhydene.2014.06.077

Escamilla-Alvarado C, Ponce-Noyola T, Ríos-Leal E, Poggi-Varaldo HM (2013) A multivariable evaluation of biohydrogen production by solid substrate fermentation of organic municipal wastes in semi-continuous and batch operation. Int J Hydrogen Energy 38:12527-12538. doi: 10.1016/j.ijhydene.2013.02.124

Fan YT, Zhang YH, Zhang SF, Hou HW, Ren BZ (2006) Efficient conversion of wheat straw wastes into biohydrogen gas by cow dung compost. Bioresour Technol 97:500-505. doi: 10.1016/j.biortech.2005.02.049

Farhat A, Miladi B, Hamdi M, Bouallagui H (2018) Fermentative hydrogen and methane co-production from anaerobic co-digestion of organic wastes at high loading rate coupling continuously and sequencing batch digesters. Environ Sci Pollut Res 25:27945-27958. doi: 10.1007/s11356-018-2796-2

460 Gavilán A, Escamilla-Alvarado C, Martínez MÁ, Ramírez T (2018) Chapter 8. Municipal solid waste management. In: Molina LT (ed) Progress and opportunities for reducing short-lived climate pollutants 
across Latin America and the Caribbean. United Nations Environment Programme and the Climate and Clean Air Coalition, pp 118-135

464 Ghimire A, Valentino S, Frunzo L, Trably E, Escudié R, Pirozzi F, Lens PNL, Esposito G (2015) Biohydrogen production from food waste by and residue post-treatment to anaerobic digestion : A synergy for energy recovery. Int J Hydrogen Energy 40:16045-16055. doi: 10.1016/j.ijhydene.2015.09.117

Giuliano A, Poletto M, Barletta D (2016) Process optimization of a multi-product biorefinery: The effect of biomass seasonality. Chem Eng Res Des 107:236-252. doi: 10.1016/j.cherd.2015.12.011

Gobierno de México (2015) Documento de Posición de México en $21^{\text {a }}$ Conferencia de las Partes de la Convención Marco de las Naciones Unidas sobre el Cambio Climático. 1-13

Gonzales RR, Sivagurunathan P, Parthiban A, Kim SH (2016) Optimization of substrate concentration of dilute acid hydrolyzate of lignocellulosic biomass in batch hydrogen production. Int Biodeterior Biodegrad 113:22-27. doi: 10.1016/j.ibiod.2016.04.016

474 Hashimoto AG (1989) Effect of inoculum/substrate ratio and pretreatments on methane yield and production rate from straw. Biol Wastes 28:247-255. doi: 10.1016/0961-9534(94)00086-9

476 Hernández-Flores G, Solorza-Feria O, Poggi-Varaldo HM (2017) Bioelectricity generation from wastewater and actual landfill leachates: A multivariate analysis using principal component analysis. Int J Hydrogen Energy 42:20772-20782. doi: 10.1016/j.ijhydene.2017.01.021

Hernández C, Escamilla-Alvarado C, Sánchez A, Alarcón E, Ziarelli F, Musule R, Valdez-Vazquez I (2019) Wheat straw, corn stover, sugarcane, and Agave biomasses: chemical properties, availability, and cellulosicbioethanol production potential in Mexico. Biofuels, Bioprod Biorefining 13:1143-1159. doi: 10.1002/bbb.2017

International Energy Agency (2016) Mexico Energy Outlook. Int Energy Agency, Paris

Joglekar SN, Pathak PD, Mandavgane SA, Kulkarni BD (2019) Process of fruit peel waste biorefinery: a case study of citrus waste biorefinery, its environmental impacts and recommendations. Environ Sci Pollut Res 26:34713-34722. doi: 10.1007/s11356-019-04196-0

Kim S, Dale BE, Jin M et al (2019) Integration in a depot-based decentralized biorefinery system: Corn stoverbased cellulosic biofuel. GCB Bioenergy 11:871-882. doi: 10.1111/gcbb.12613

Kumar S, Dheeran P, Singh SP, Mishra IM, Adhikari DK (2015) Kinetic studies of two-stage sulphuric acid hydrolysis of sugarcane bagasse. Renew Energy 83:850-858. doi: 10.1016/j.renene.2015.05.033

Kumari S, Das D (2019) Biohythane production from sugarcane bagasse and water hyacinth: A way towards promising green energy production. J Clean Prod 207:689-701. doi: 10.1016/j.jclepro.2018.10.050

Li K, Liu R, Sun C (2016) A review of methane production from agricultural residues in China. Renew Sustain Energy Rev 54:857-865. doi: 10.1016/j.rser.2015.10.103

Li Y, Park SY, Zhu J (2011) Solid-state anaerobic digestion for methane production from organic waste. Renew Sustain Energy Rev 15:821-826. doi: 10.1016/j.rser.2010.07.042

Liu CM, Chu CY, Lee WY, Li YC, Wu SY, Chou YP (2013) Biohydrogen production evaluation from rice straw hydrolysate by concentrated acid pre-treatment in both batch and continuous systems. Int J Hydrogen Energy 38:15823-15829. doi: 10.1016/j.ijhydene.2013.07.055

Lo HM, Kurniawan TA, Sillanpää MET et al (2010) Modeling biogas production from organic fraction of MSW co-digested with MSWI ashes in anaerobic bioreactors. Bioresour Technol 101:6329-6335. doi: 10.1016/j.biortech.2010.03.048

Luo G, Talebnia F, Karakashev D, Xie L, Zhou Q, Angelidaki I (2011) Enhanced bioenergy recovery from rapeseed plant in a biorefinery concept. Bioresour Technol 102:1433-1439. doi: 10.1016/j.biortech.2010.09.071

Mahlia TMI, Ismail N, Hossain N, Silitonga AS, Shamsuddin AH (2019) Palm oil and its wastes as bioenergy sources: a comprehensive review. Environ Sci Pollut Res. doi: 10.1007/s11356-019-04563-x

508 Miller GL (1959) Use of dinitrosalicylic acid reagent for determination of reducing sugar. Anal Chem 31:426428. doi: 10.1021/ac60147a030

510 Moncada-Botero J, Aristizábal-Marulanda V, Cardona-Alzate CA (2016) Design strategies for sustainable biorefineries. Biochem Eng J 116:122-134. doi: 10.1016/j.bej.2016.06.009

512 Moset V, Al-zohairi N, Moller HB (2015) The impact of inoculum source, inoculum to substrate ratio and sample 
preservation on methane potential from different substrates. Biomass and Bioenergy 83:474-482. doi: 10.1016/j.biombioe.2015.10.018

NMX-AA-25-1984 (1992) Norma Mexicana NMX-AA-25-1984. Protección al ambiente-Contaminación del suelo-residuos sólidos-determinación del pH-Método potenciométrico. Norma Mex 4-5

Oliwit AT, Cayetano RDA, Kumar G, Kim JS, Kim SH (2019) Comparative evaluation of biochemical methane potential of various types of Ugandan agricultural biomass following soaking aqueous ammonia pretreatment. Environ Sci Pollut Res. doi: 10.1007/s11356-019-07190-8

Ozmihci S, Kargi F, Cakir A (2011) Thermophilic dark fermentation of acid hydrolyzed waste ground wheat for hydrogen gas production. Int J Hydrogen Energy 36:2111-2117. doi: 10.1016/j.ijhydene.2010.11.033

\section{4}

Purwadi R, Niklasson C, Taherzadeh MJ (2004) Kinetic study of detoxification of dilute-acid hydrolyzates by $\mathrm{Ca}(\mathrm{OH})$ 2. J Biotechnol 114:187-198. doi: 10.1016/j.jbiotec.2004.07.006

\section{6}

Ren N, Cao G, Wang A, Lee DJ, Guo W, Zhu Y (2008) Dark fermentation of xylose and glucose mix using isolated Thermoanaerobacterium ihermosaccharolyticum W16. Int J Hydrogen Energy 33:6124-6132. doi: 10.1016/j.ijhydene.2008.07.107

Rodríguez-Valderrama S (2018) Enfoque de Biorrefienría para la Producción de Hidrógeno y Metano a partir de residuos Orgánicos. Universidad Autónoma de Nuevo León

Rodríguez-Valderrama S, Escamilla-Alvarado C, Amezquita-Garcia HJ, Cano-Gómez JJ, Magnin JP, RivasGarcía P (2019) Evaluation of feeding strategies in upflow anaerobic sludge bed reactor for hydrogenogenesis at psychrophilic temperature. Int J Hydrogen Energy 44:12346-12355. doi: 10.1016/j.ijhydene.2018.09.215

Romero-Cedillo L, Poggi-Varaldo HM, Ponce-Noyola T, Ríos-Leal E, Ramos-Valdivia AC, Cerda-García Rojas

\section{6} production in the context of an OFMSW biorefinery. J. Chem. Technol. Biotechnol. 92:937-958

\section{8}

Roy S, Das D (2016) Biohythane production from organic wastes: present state of art. Environ Sci Pollut Res 23:9391-9410. doi: 10.1007/s11356-015-5469-4

SADER (2019) Expectativas de producción agropecuaria y pesquera, Mayo 2019

Saha BC, Iten LB, Cotta MA, Wu YV (2005) Dilute acid pretreatment, enzymatic saccharification and fermentation of wheat straw to ethanol. Process Biochem 40:3693-3700. doi: 10.1016/j.procbio.2005.04.006

Sluiter A, Ruiz R, Scarlata C, Sluiter J, Templeton D (2008) Determination of extractives in biomass. NREL

Sultana A, Kumar A (2011) Optimal configuration and combination of multiple lignocellulosic biomass feedstocks delivery to a biorefinery. Bioresour Technol 102:9947-9956. doi: 10.1016/j.biortech.2011.07.119

Taboada-González P, Aguilar-Virgen Q, Ojeda-Benítez S, Armijo C (2011) Waste characterization and waste management perception in rural communities in Mexico: A case study. Environ Eng Manag J 10:1751-1759. doi: 10.30638/eemj.2011.238

Tan L, Liu Z, Liu T, Wang F (2019) Efficient fractionation of corn stover by bisulfite pretreatment for the production of bioethanol and high value products. BioResources 14:6501-6515

Tapia-Rodríguez A, Ibarra-Faz E, Razo-Flores E (2019) Hydrogen and methane production potential of agave bagasse enzymatic hydrolysates and comparative technoeconomic feasibility implications. Int J Hydrogen Energy 44:17792-17801. doi: 10.1016/j.ijhydene.2019.05.087

Varanasi JL, Kumari S, Das D (2018) Improvement of energy recovery from water hyacinth by using integrated system. Int J Hydrogen Energy 43:1303-1318. doi: 10.1016/j.ijhydene.2017.11.110

Wang J, Wan W (2009) Kinetic models for fermentative hydrogen production: A review. Int J Hydrogen Energy 34:3313-3323. doi: 10.1016/j.ijhydene.2009.02.031

Wang W, Xie L, Chen J, Luo G, Zhou Q (2011) Biohydrogen and methane production by co-digestion of cassava stillage and excess sludge under thermophilic condition. Bioresour Technol 102:3833-3839. doi: 10.1016/j.biortech.2010.12.012

Wong YM, Wu TY, Ching-Juan J (2014) A review of sustainable hydrogen production using seed sludge via dark fermentation. Renew Sustain Energy Rev 34:471-482. doi: 10.1016/j.rser.2014.03.008

Xia A, Cheng J, Lin R, Lu H, Zhou J, Cen K (2013) Comparison in dark hydrogen fermentation followed by photo hydrogen fermentation and methanogenesis between protein and carbohydrate compositions in Nannochloropsis oceanica biomass. Bioresour Technol 138:204-213. doi: 10.1016/j.biortech.2013.03.171 
564 Yan L, Zhang H, Chen J, Lin Z, Jin Q, Jia H, Huang H (2009) Dilute sulfuric acid cycle spray flow-through pretreatment of corn stover for enhancement of sugar recovery. Bioresour Technol 100:1803-1808. doi:

$566 \quad$ 10.1016/j.biortech.2008.10.001

Zhang K, Ren N, Wang A (2015) Fermentative hydrogen production from corn stover hydrolyzate by two typical seed sludges : Effect of temperature. Int J Hydrogen Energy 40:3838-3848. doi: 10.1016/j.ijhydene.2015.01.120

570 Zhang W, Wei Q, Wu S, Qi D, Li W, Zuo Z, Dong R (2014) Batch anaerobic co-digestion of pig manure with dewatered sewage sludge under mesophilic conditions. Appl Energy 128:175-183. doi: 10.1016/j.apenergy.2014.04.071

Zhu J, Wan C, Li Y (2010) Enhanced solid-state anaerobic digestion of corn stover by alkaline pretreatment. Bioresour Technol 101:7523-7528. doi: 10.1016/j.biortech.2010.04.060

\begin{tabular}{|c|c|c|}
\hline \multirow[t]{2}{*}{578} & $\mathrm{AD}$ & Anaerobic digestion \\
\hline & $B(t)$ & Cumulative methane production $\left(\mathrm{mmol} \mathrm{CH}_{4}\right)$ \\
\hline \multirow[t]{2}{*}{580} & $B_{\max }$ & Maximum cumulative methane production $\left(\mathrm{mmol} \mathrm{CH}_{4}\right)$ \\
\hline & $b(t)$ & Cumulative specific methane production $\left(\mathrm{mmol} \mathrm{CH} 4 / \mathrm{g}_{\mathrm{vs}}\right)$ \\
\hline \multirow[t]{2}{*}{582} & $b_{\max }$ & Maximum cumulative specific methane production $\left(\mathrm{mmol} \mathrm{CH} / \mathrm{g}_{\mathrm{vs}}\right)$ \\
\hline & $\mathrm{CS}$ & Corn stover \\
\hline \multirow[t]{2}{*}{584} & $C_{R S, 0}$ & Initial reducing sugars concentration $(\mathrm{g} / \mathrm{L})$ \\
\hline & $C_{R S, f}$ & Final reducing sugars concentration $(\mathrm{g} / \mathrm{L})$ \\
\hline \multirow[t]{2}{*}{586} & DF & Dark fermentation \\
\hline & $e$ & Euler number $(2.718)$ \\
\hline \multirow[t]{2}{*}{588} & $\hat{E}_{p}$ & Specific gross energy potential $\left(\mathrm{kJ} / \mathrm{g}_{\mathrm{vs}}\right)$ \\
\hline & FVW & Fruits and vegetables wastes \\
\hline \multirow[t]{2}{*}{590} & $h$ & Diluted acid pretreatment stage \\
\hline & $H$ & Hydrogen production stage by DF \\
\hline \multirow[t]{2}{*}{592} & $H(t)$ & Cumulative hydrogen specific production (mL $\left.\mathrm{H}_{2} / \mathrm{g}_{\text {glucose }}\right)$ \\
\hline & $H_{\max }$ & Maximum cumulative specific hydrogen production $\left(\mathrm{mL} \mathrm{H}_{2} / \mathrm{g}_{\text {glucose }}\right)$ \\
\hline \multirow[t]{2}{*}{594} & $h-H-M$ & Biorefinery model \\
\hline & $H H V_{H 2}$ & High hydrogen heating value $(282.8 \mathrm{~kJ} / \mathrm{mol})$ \\
\hline \multirow[t]{2}{*}{596} & $H H V_{C H 4}$ & High methane heating value $(889.9 \mathrm{~kJ} / \mathrm{mol})$ \\
\hline & $\mathrm{HMF}$ & 5-hydroxymethylfurfural \\
\hline \multirow[t]{2}{*}{598} & HS & Hydrolyzed solids \\
\hline & ISR & Inoculum to substrate ratio \\
\hline \multirow[t]{2}{*}{600} & $k$ & Methane production rate $(1 / d)$ \\
\hline & LH & Liquid hydrolyzates \\
\hline \multirow[t]{2}{*}{602} & $M$ & Methane production stage by AD \\
\hline & $M W_{\text {glucose }}$ & Glucose molar weight $(180.16 \mathrm{~g} / \mathrm{mol})$ \\
\hline \multirow[t]{2}{*}{604} & ND & Not determined \\
\hline & $\mathrm{pH}_{0}$ & Initial pH \\
\hline \multirow[t]{2}{*}{606} & $r_{\max , M}$ & Maximum specific methane production rate $\left(\mathrm{mmol} /\left(\mathrm{g}_{\mathrm{vs}} \mathrm{d}\right)\right)$ \\
\hline & $r_{\max , H}$ & Maximum specific hydrogen production rate $(\mathrm{mL} /($ gglucose $\mathrm{h}))$, \\
\hline \multirow[t]{2}{*}{608} & $R_{\max , M}$ & Maximum methane production rate $(\mathrm{mmol} / \mathrm{d})$ \\
\hline & $\mathrm{R}^{2}$ & Coefficient of determination \\
\hline
\end{tabular}




$\begin{array}{lll}610 & \text { RS } & \text { Reducing sugars } \\ & \text { T } & \text { Operational temperature } \\ 612 & t & \text { Time } \\ & \text { TPC } & \text { Total phenolic compounds } \\ 614 & \text { TS } & \text { Total solids } \\ & \text { TVFA } & \text { Total volatile fatty acids } \\ 616 & V_{M} & \text { Molar volume at standard conditions }\left(22.4 \mathrm{~L} / \mathrm{mol} \mathrm{H}_{2} \mathrm{or}_{\mathrm{CH}}\right) \\ & \text { VO } & \text { Operational volume } \\ 618 & \text { VS } & \text { Volatile solids } \\ & Y^{\prime}{ }^{\prime}{ }_{2} & \text { Hydrogen molar pseudoyield }\left(\mathrm{mol} \mathrm{H}_{2} / \mathrm{mol}_{\text {glucose }}\right) \\ 620 & & \end{array}$

\section{Subindices}

$\begin{array}{lll}\text { db } & \text { dry basis } \\ 624 & \text { wb } & \text { wet basis }\end{array}$

\section{Greek characters}

$628 \lambda \quad$ adaptation time (h or d)

$\eta_{A H} \quad$ Acid hydrolysis efficiency ( $\mathrm{g}_{\mathrm{glucos}} / \mathrm{g}_{\mathrm{vs}}$ )

$630 \eta_{\mathrm{DF}} \quad$ Dark fermentation efficiency $\left(\mathrm{g}_{\mathrm{vs}}\right.$ consumed $/ \mathrm{g}_{\mathrm{vs}}$ added) 


\section{$632 \quad$ List of Tables}

Table 1 Characteristic of co-substrates (FVW and CS) and HS

634 Table 2 Equations used to describe the $H$ and $M$ stages and the biorefinery performance

Table 3 Main sugar production and secondary products from acid hydrolysis pretreatment of co-substrates $636 \quad(3: 1 \mathrm{FVW}: \mathrm{CS})$

Table 4 Gompertz coefficients and performance parameters from dark fermentation of LH

638 Table 5 Kinetic parameters comparison between the first-order model and Gompertz model on the maximum cumulative methane production $\left(B_{\max }\right.$ ) during anaerobic digestion of HS and FVW

640 Table 6 Kinetic parameters comparison between the first-order model and Gompertz model on the maximum cumulative specific methane production $\left(b_{\max }\right.$ ) during anaerobic digestion of HS and FVW

642 Table 7 Biorefinery process conditions and energy yields

644

646

648

650 
652 Table 1 Characteristic of co-substrates (FVW and CS) and HS

\begin{tabular}{llll}
\hline Parameter & FVW & CS & HS \\
\hline pH & 5.52 & 7.54 & 3.66 \\
Moisture (\%wb) & 89.81 & 5.41 & 84.00 \\
TS (\%wb) & 10.19 & 94.59 & 16.00 \\
VS (\%db) & 87.66 & 89.78 & 93.43 \\
Ashes (\%db) & 12.34 & 10.22 & 6.57 \\
Alkalinity (mg CaCO $/ \mathrm{L})$ & 475 & 450 & 200 \\
Total Volatile fatty acids (mg VFA/L) & 570 & 420 & 220 \\
Cellulose (\%db) & 12.80 & 33.25 & 24.86 \\
Hemicellulose (\%db) & 24.40 & 24.35 & 17.81 \\
Lignin (\%db) & 10.26 & 24.74 & 16.29 \\
Protein (\%db) & 12.63 & 3.25 & 12.14 \\
Extractives (\%db) & 38.11 & 10.19 & $\mathrm{ND}$ \\
$\mathrm{C}(\% \mathrm{db})$ & 51.69 & 43.84 & 56.19 \\
$\mathrm{H}(\% \mathrm{db})$ & 3.43 & 15.74 & 10.74 \\
O (\%db) & 42.69 & 39.98 & 31.15 \\
$\mathrm{~N}(\% \mathrm{db})$ & 2.19 & 0.44 & 1.92 \\
\hline Abbriations
\end{tabular}

654 Abbreviations: CS, corn stover; db, dry base; FVW, fruits

656 
Table 2 Equations used to describe the $H$ and $M$ stages and the biorefinery performance

\begin{tabular}{|c|c|c|}
\hline Response variable & Equation & $\begin{array}{l}\text { Equation } \\
\text { number }\end{array}$ \\
\hline $\begin{array}{l}\text { Cumulative hydrogen specific } \\
\text { production }\end{array}$ & $H(t)=H_{\max } \cdot \exp \left\{-\exp \left[\frac{R_{\max , H^{\prime}} \cdot e}{H_{\max }}(\lambda-t)+1\right]\right\}$ & (1) \\
\hline Hydrogen molar pseudoyield & $Y_{H_{2}}^{\prime}=\frac{H_{\max } \cdot C_{R S, 0} \cdot\left(M W_{\text {glucose }}\right)}{\left(C_{R S, 0}-C_{R S, f}\right) \cdot\left(V_{M}\right) \cdot 1000}$ & (2) \\
\hline $\begin{array}{l}\text { Cumulative methane production } \\
\text { (Gompertz-modified model) }\end{array}$ & $B(t)=B_{\max } \cdot \exp \left\{-\exp \left[\frac{R_{\max , M^{\prime}} e}{B_{0}}(\lambda-t)+1\right]\right\}$ & (3) \\
\hline $\begin{array}{l}\text { Cumulative specific methane } \\
\text { production (Gompertz-modified } \\
\text { model) }\end{array}$ & $b(t)=b_{\max } \cdot \exp \left\{-\exp \left[\frac{r_{\max , M^{\prime}} \cdot e}{b_{0}}(\lambda-t)+1\right]\right\}$ & (4) \\
\hline $\begin{array}{l}\text { Cumulative methane production } \\
\text { (first-order kinetic model) }\end{array}$ & $B(t)=B_{\max } \cdot\left(1-\exp ^{-k \cdot t}\right)$ & (5) \\
\hline $\begin{array}{l}\text { Cumulative specific methane } \\
\text { production (first-order kinetic } \\
\text { model) }\end{array}$ & $b(t)=b_{\max } \cdot\left(1-\exp ^{-k \cdot t}\right)$ & (6) \\
\hline $\begin{array}{l}\text { Specific gross energy potential } \\
\text { for serial hydrogen and methane } \\
\text { production }\end{array}$ & $\hat{E}_{P}=\frac{1}{V_{M} \cdot 1000} \cdot\left(H_{\max } \cdot H H V_{H_{2}}+\left(1-\eta_{D F}\right) \cdot b_{\max } \cdot H H V_{C H_{4}}\right)$ & (7) \\
\hline $\begin{array}{l}\text { Specific gross energy potential } \\
\text { for parallel hydrogen and } \\
\text { methane production }\end{array}$ & $\hat{E}_{P}=\frac{1}{V_{M} \cdot 1000} \cdot\left(\eta_{A H} \cdot H_{\max } \cdot H H V_{H_{2}}+\left(1-\eta_{A H}\right) \cdot b_{\max } \cdot H H V_{C H_{4}}\right)$ & (8) \\
\hline
\end{tabular}


662 Table 3 Main sugar production and secondary products from acid hydrolysis pretreatment of co-substrates (3:1 FVW:CS)

\begin{tabular}{lcc}
\hline Parameter & LH before overliming & LH after overliming \\
\hline RS $(\mathrm{g} / \mathrm{L})$ & 23.49 & 21.13 \\
Glucose $(\mathrm{g} / \mathrm{L})$ & 10.36 & 9.65 \\
Xylose $(\mathrm{g} / \mathrm{L})$ & 8.61 & 8.36 \\
Arabinose $(\mathrm{g} / \mathrm{L})$ & 0.39 & 0.07 \\
HMF $(\mathrm{g} / \mathrm{L})$ & 0.65 & $\mathrm{ND}$ \\
Furfural $(\mathrm{g} / \mathrm{L})$ & 0.14 & $\mathrm{ND}$ \\
TPC $(\mathrm{g} / \mathrm{L})$ & 1.14 & 0.76 \\
Formic acid $(\mathrm{g} / \mathrm{L})$ & 4.02 & $\mathrm{ND}$ \\
Acetic acid $(\mathrm{g} / \mathrm{L})$ & 0.53 & $\mathrm{ND}$ \\
\hline
\end{tabular}

664 Abbreviations: HMF, 5-hydroxymethylfurfural; ND, not detected; LH, liquid hydrolyzates; RS, reducing sugars; TPC, total phenolic compounds. 
Table 4 Gompertz coefficients and performance parameters from dark fermentation of LH

\begin{tabular}{|c|c|}
\hline Parameter & Value \\
\hline$H_{\max }\left(\mathrm{mL} \mathrm{H} \mathrm{H}_{2} / \mathrm{g}_{\text {glucose }}\right)$ & $223.8 \pm 5.2$ \\
\hline$R_{\max , H}\left(\mathrm{~mL} \mathrm{H} /\left(\mathrm{g}_{\text {glucose }} \mathrm{h}\right)\right)$ & $2.60 \pm 0.08$ \\
\hline$\lambda(\mathrm{h})$ & $19.25 \pm 0.52$ \\
\hline $\mathrm{R}^{2}$ & 0.99 \\
\hline Final $\mathrm{pH}$ & $5.34 \pm 0.60$ \\
\hline Acetic acid (g/L) & $1.11 \pm 0.007$ \\
\hline Propionic acid (g/L) & $0.36 \pm 0.011$ \\
\hline Butyric acid (g/L) & $6.13 \pm 0.265$ \\
\hline Ethanol $(\mathrm{g} / \mathrm{L})$ & $0.07 \pm 0.003$ \\
\hline Sugars consumption (\%) & $89.30 \pm 0.4$ \\
\hline Volumetric productivity $\left(\mathrm{mL} \mathrm{H}_{2} / \mathrm{L}_{\text {reactor }}\right)$ & $2909 \pm 67.8$ \\
\hline$Y_{H 2}^{\prime}\left(\mathrm{mol} \mathrm{H}_{2} / \mathrm{mol}_{\text {glucose }}\right)$ & $2.02 \pm 0.05$ \\
\hline
\end{tabular}

670 Abbreviations: $H_{\max }$, maximum cumulative specific hydrogen production; $R_{\max , H}$, maximum specific hydrogen production rate; $\mathbf{R}^{2}$, coefficient of determination; $Y_{H 2}^{\prime}$, hydrogen molar pseudoyield; $\lambda$, adaptation time. 
672 Table 5 Kinetic parameters comparison between the first-order model and Gompertz model on the maximum cumulative methane production $\left(B_{\max }\right.$ ) during anaerobic digestion of HS and FVW

\begin{tabular}{lllllll}
\hline Model & \multicolumn{3}{l}{ ISR-substrate type } & & & \\
\cline { 2 - 7 } & 2-HS & $2.5-\mathrm{HS}$ & $3-\mathrm{HS}$ & $3.5-\mathrm{HS}$ & 4-HS & 3-FVW \\
\hline Experimental $B_{\max }\left(\mathrm{mmol} \mathrm{CH}_{4}\right)$ & 7.59 & 8.78 & 7.70 & 6.37 & 8.19 & 7.74 \\
First-order & & & & & & \\
$B_{\max }\left(\mathrm{mmol} \mathrm{CH}_{4}\right)$ & 7.85 & 8.89 & 8.09 & 6.84 & 8.40 & $\mathrm{NA}$ \\
$k(1 / \mathrm{d})$ & 0.23 & 0.28 & 0.23 & 0.19 & 0.25 & $\mathrm{NA}$ \\
$\mathrm{R}^{2}$ & 0.99 & 0.99 & 0.99 & 0.99 & 0.99 & $\mathrm{NA}$ \\
Error $(\%)$ & 3.47 & 1.29 & 5.09 & 7.36 & 2.62 & $\mathrm{NA}$ \\
Gompertz & & & & & & \\
$B_{\max }\left(\mathrm{mmol} \mathrm{CH}_{4}\right)$ & 7.39 & 8.49 & 7.69 & 6.32 & 7.93 & 8.01 \\
$R_{\max , M}\left(\mathrm{mmol} \mathrm{CH}_{4} / \mathrm{d}\right)$ & 1.18 & 1.67 & 1.14 & 0.82 & 1.41 & 1.03 \\
$\lambda(\mathrm{d})$ & 0.00 & 0.00 & 0.00 & 0.00 & 0.00 & 1.46 \\
$\mathrm{R}^{2}$ & 0.99 & 0.99 & 0.99 & 0.99 & 0.99 & 0.99 \\
Error $(\%)$ & 2.61 & 3.36 & 0.11 & 0.87 & 3.07 & 3.49 \\
\hline $\mathrm{A}$ & &
\end{tabular}

674 Abbreviations: $B_{\max }$, maximum cumulative methane production; $k$, methane production rate; HS, hydrolyzed solids; FVW, fruits and vegetables wastes; NA, not applicable; $R_{\max , M}$, maximum methane production rate; $\mathrm{R}^{2}$, coefficient of determination; $\lambda$, 676 adaptation time.

678

Note: range of final $\mathrm{pH}$ values 7.53-7.72. 
680 Table 6 Kinetic parameters comparison between the first-order model and Gompertz model on the maximum cumulative specific methane production $\left(b_{\max }\right.$, ) during anaerobic digestion of $\mathrm{HS}$ and FVW

\begin{tabular}{|c|c|c|c|c|c|c|}
\hline \multirow[t]{2}{*}{ Model } & \multicolumn{6}{|c|}{ ISR-substrate } \\
\hline & 2-HS & 2.5-HS & $3-\mathrm{HS}$ & $3.5-\mathrm{HS}$ & 4-HS & 3-FVW \\
\hline Experimental $b_{\max }\left(\mathrm{mmol} \mathrm{CH}_{4} / \mathrm{g}_{\mathrm{vS}}\right)$ & 5.84 & 8.78 & 9.63 & 9.10 & 13.64 & 9.67 \\
\hline \multicolumn{7}{|l|}{ First-order } \\
\hline$b_{\max }\left(\mathrm{mmol} \mathrm{CH} / \mathrm{g}_{\mathrm{VS}}\right)$ & 6.04 & 8.89 & 10.12 & 9.77 & 14.00 & NA \\
\hline$k(1 / \mathrm{d})$ & 0.23 & 0.28 & 0.23 & 0.19 & 0.25 & NA \\
\hline $\mathrm{R}^{2}$ & 0.99 & 0.99 & 0.99 & 0.99 & 0.99 & NA \\
\hline Error $(\%)$ & 3.47 & 1.29 & 5.09 & 7.36 & 2.62 & NA \\
\hline \multicolumn{7}{|l|}{ Gompertz. } \\
\hline$b_{\max }\left(\mathrm{mmol} \mathrm{CH}_{4} / \mathrm{g}_{\mathrm{vs}}\right)$ & 5.68 & 8.49 & 9.62 & 9.02 & 13.22 & 10.01 \\
\hline$r_{\max , M}\left(\mathrm{mmol} \mathrm{CH}_{4} /\left(\mathrm{g}_{\mathrm{Vs}} \mathrm{d}\right)\right)$ & 0.90 & 1.67 & 1.43 & 1.18 & 2.35 & 1.29 \\
\hline$\lambda$ & 0.00 & 0.00 & 0.00 & 0.00 & 0.00 & 1.46 \\
\hline $\mathrm{R}^{2}$ & 0.99 & 0.99 & 0.99 & 0.99 & 0.99 & 0.99 \\
\hline Error $(\%)$ & 2.61 & 3.36 & 0.11 & 0.87 & 3.07 & 1.46 \\
\hline
\end{tabular}

682 Abbreviations: $b_{\max }$, maximum cumulative specific methane production; $k$, methane production rate; HS, hydrolyzed solids; FVW, fruits and vegetables wastes; NA, not applicable; $r_{\max , M}$, maximum specific methane production rate; $\mathrm{R}^{2}$, coefficient of 684 determination; $\lambda$, adaptation time. Note: range of final $\mathrm{pH}$ values 7.53-7.72. 
Table 7 Biorefinery process conditions and energy yields

\begin{tabular}{|c|c|c|c|c|c|c|}
\hline Substrate & $\begin{array}{c}\text { Substrate } \\
\text { pretreatment }\end{array}$ & Process & $\begin{array}{c}\text { Dark } \\
\text { fermentation }\end{array}$ & $\begin{array}{l}\text { Anaerobic } \\
\text { digestion }\end{array}$ & $\begin{array}{c}\hat{E}_{P} \\
\left(\mathrm{~kJ} / \mathrm{g}_{\mathrm{VS}}\right)\end{array}$ & Reference \\
\hline Rapeseed straw & $\begin{array}{c}\text { Alkaline } \\
\text { peroxide } \\
(3 \% \mathrm{v} / \mathrm{v}) \\
\text { and steam }(18 \\
{ }^{\circ} \mathrm{C} \\
10 \mathrm{~min})\end{array}$ & $\begin{array}{l}\text { Serial two-stage: } \\
\text { DF (batch) + AD } \\
\text { (batch) }\end{array}$ & $\begin{array}{c}\mathrm{V}_{\mathrm{o}}=60 \mathrm{~mL} \\
\mathrm{~T}=55^{\circ} \mathrm{C} \\
\mathrm{pH} \mathrm{H}_{\mathrm{o}}=5.5 \\
H_{\max }=91 \mathrm{~mL} \\
\mathrm{H}_{2} / \mathrm{g}_{\mathrm{VS}}\end{array}$ & $\begin{array}{c}\mathrm{V}_{\mathrm{o}}=60 \mathrm{~mL} \\
\mathrm{~T}=55^{\circ} \mathrm{C} \\
\mathrm{pH} \mathrm{H}_{\mathrm{o}}=7.5 \\
b_{\max }=370 \mathrm{~mL} \\
\mathrm{CH}_{4} / \mathrm{g}_{\mathrm{VS}}\end{array}$ & 13.2 & $\begin{array}{l}\text { Luo et al. } \\
\text { (2011) }\end{array}$ \\
\hline $\begin{array}{l}\text { Nannochloropsis } \\
\text { oceanica }\end{array}$ & $\begin{array}{c}\text { Microwave } \\
\left(140{ }^{\circ} \mathrm{C}, 15\right. \\
\text { min, } 1.0 \% \\
\mathrm{H}_{2} \mathrm{SO}_{4}, 50 \mathrm{~g} / \mathrm{I}\end{array}$ & $\begin{array}{l}\text { Serial two-stage: } \\
\text { DF (batch) + AD } \\
\text { (batch) }\end{array}$ & $\begin{array}{c}\mathrm{V}_{\mathrm{o}}=250 \mathrm{~mL} \\
\mathrm{~T}=35^{\circ} \mathrm{C} \\
\mathrm{pH} \mathrm{H}_{\mathrm{o}}=6.0 \\
H_{\max }=39 \mathrm{~mL} \\
\mathrm{H}_{2} / \mathrm{g}_{\mathrm{VS}}\end{array}$ & $\begin{array}{c}\mathrm{V}_{\mathrm{o}}=250 \mathrm{~mL} \\
\mathrm{~T}=35^{\circ} \mathrm{C} \\
\mathrm{pH}{ }_{0}=8.0 \\
b_{\max }=114 \\
\mathrm{~mL} \mathrm{CH}_{4} / \mathrm{g}_{\mathrm{VS}}\end{array}$ & 4.7 & $\begin{array}{l}\text { Xia et al. } \\
\text { (2013) }\end{array}$ \\
\hline Food waste & NA & $\begin{array}{l}\text { Serial DF (semi- } \\
\text { continuous) and AD } \\
\text { (batch) }\end{array}$ & $\begin{array}{c}\mathrm{V}_{\mathrm{o}}=1500 \mathrm{~mL} \\
\mathrm{~T}=55^{\circ} \mathrm{C} \\
\mathrm{pH} \mathrm{H}_{0}=7.0 \\
H_{\max }=104 \mathrm{~mL} \\
\mathrm{H}_{2} / \mathrm{g}_{\mathrm{VS}}\end{array}$ & $\begin{array}{c}\mathrm{V}_{\mathrm{o}}=600 \mathrm{~mL} \\
\mathrm{~T}=34^{\circ} \mathrm{C} \\
\mathrm{pH}_{\mathrm{o}}=7 \\
b_{\max }=99.3 \\
\mathrm{~mL} \mathrm{CH}_{4} / \mathrm{g}_{\mathrm{VS}}\end{array}$ & 4.4 & $\begin{array}{l}\text { Ghimire et al. } \\
\text { (2015) }\end{array}$ \\
\hline $\begin{array}{l}\text { Organic fraction } \\
\text { of municipal solid } \\
\text { wastes }\end{array}$ & NA & $\begin{array}{l}\text { Serial two-stage } \\
\text { DF (semi-continuous) } \\
\quad+\mathrm{AD} \text { (semi- } \\
\text { continuous) }\end{array}$ & $\begin{array}{c}\mathrm{V}_{\mathrm{o}}=500 \mathrm{~g} \\
\mathrm{~T}=55^{\circ} \mathrm{C} \\
\mathrm{pH}_{\mathrm{o}}=8.0 \\
H_{\max }=33.3 \mathrm{~mL} \\
\mathrm{H}_{2} / \mathrm{g}_{\mathrm{VS}}\end{array}$ & $\begin{array}{c}\mathrm{V}_{\mathrm{o}}=500 \mathrm{~g} \\
\mathrm{~T}=55^{\circ} \mathrm{C} \\
\mathrm{pH}_{\mathrm{o}}=8.0 \\
b_{\max }=353 \\
\mathrm{~mL} \mathrm{CH} \mathrm{CH}_{4} / \mathrm{g}_{\mathrm{VS}}\end{array}$ & 13.5 & $\begin{array}{l}\text { Escamilla- } \\
\text { Alvarado et al } \\
\text { (2014) }\end{array}$ \\
\hline $\begin{array}{l}\text { Sugarcane } \\
\text { bagasse and water } \\
\text { hyacinth } \\
(1: 2 \text { ratio })\end{array}$ & $\begin{array}{c}\text { Alkaline } \\
\text { peroxide } \\
(2.5 \% \mathrm{v} / \mathrm{v}, \\
50^{\circ} \mathrm{C}, 150 \mathrm{mir} \\
\text { and enzymati } \\
\text { hydrolysis } \\
(\text { Cellulase }, 2: \\
\mathrm{U} / \mathrm{g}_{\mathrm{db}}, 37^{\circ} \mathrm{C} \\
180 \mathrm{rpm}, 48 \mathrm{r}\end{array}$ & $\begin{array}{l}\text { Serial two-stage } \\
\text { DF (continuous) }+\mathrm{AD} \\
\quad \text { (continuous) }\end{array}$ & $\begin{array}{c}\mathrm{V}_{\mathrm{o}}=500 \mathrm{~mL} \\
\mathrm{~T}=37{ }^{\circ} \mathrm{C} \\
\mathrm{pH} \mathrm{H}_{\mathrm{o}}=6.5 \\
H_{\max }=303 \mathrm{~mL} \\
\mathrm{H}_{2} / \mathrm{g}_{\mathrm{VS}}\end{array}$ & $\begin{array}{c}\mathrm{V}_{\mathrm{o}}=4000 \mathrm{~mL} \\
\mathrm{~T}=37{ }^{\circ} \mathrm{C} \\
\mathrm{pH}=7.5 \\
b_{\max }=142 \\
\mathrm{~mL} \mathrm{CH} \mathrm{CH}_{4} / \mathrm{g}_{\mathrm{VS}}\end{array}$ & 6.0 & $\begin{array}{l}\text { Kumari and } \\
\text { Das (2019) }\end{array}$ \\
\hline Water hyacinth & NA & $\begin{array}{l}\text { Serial two-stage } \\
\text { DF (semi-continuous) } \\
+ \text { AD (semi- } \\
\text { continuous) }\end{array}$ & $\begin{array}{c}\mathrm{V}_{\mathrm{o}}=500 \mathrm{~mL} \\
\mathrm{~T}=37^{\circ} \mathrm{C} \\
\mathrm{pH} H_{0}=6.5 \\
H_{\text {max }}=93 \mathrm{~mL} \\
\mathrm{H}_{2} / \mathrm{g}_{\mathrm{VS}}\end{array}$ & $\begin{array}{c}\mathrm{V}_{\mathrm{o}}=500 \mathrm{~mL} \\
\mathrm{~T}=37^{\circ} \mathrm{C} \\
\mathrm{pH} \mathrm{H}_{0}=7.5 \\
b_{\max }=270.5 \\
\mathrm{~mL} \mathrm{CH}_{4} / \mathrm{g}_{\mathrm{Vs}}\end{array}$ & 2.6 & $\begin{array}{l}\text { Varanasi et al. } \\
\quad(2018)\end{array}$ \\
\hline Corn stover & $\begin{array}{c}\text { Steam- } \\
\text { explosion } \\
\left(220^{\circ} \mathrm{C}, 3 \mathrm{mi}\right] \\
\text { water- } \\
\text { impregned })\end{array}$ & Parallel DF & $\begin{array}{c}\mathrm{V}_{\mathrm{o}}=1250 \mathrm{~mL} \\
\mathrm{~T}=35^{\circ} \mathrm{C} \\
\mathrm{pH}=5.5 \\
H_{\max }=304.3 \\
\mathrm{~mL} \mathrm{H} / \mathrm{g}_{\mathrm{VS}}\end{array}$ & $\begin{array}{c}\mathrm{V}_{\mathrm{o}}=1250 \mathrm{~mL} \\
\mathrm{~T}=35^{\circ} \mathrm{C} \\
\mathrm{pH}=5.5 \\
H_{\max }=152.3 \\
\mathrm{~mL} \mathrm{H} / \mathrm{g}_{\mathrm{VS}}\end{array}$ & 2.24 & $\begin{array}{l}\text { Datar et al. } \\
\text { (2007) }\end{array}$ \\
\hline $\begin{array}{c}\text { Organic wastes } \\
\text { (FVW-40\%, } \\
\text { WAS-40\%, } \\
\text { OMW-10\%, CM- } \\
10 \% \text { ) }\end{array}$ & NA & $\begin{array}{l}\text { Serial two-stage DF } \\
\text { (continuous) and AD } \\
\text { (continuous) }\end{array}$ & $\begin{array}{c}\mathrm{V}_{\mathrm{o}}=800 \mathrm{~mL} \\
\mathrm{~T}=37{ }^{\circ} \mathrm{C} \\
\mathrm{pH}_{\mathrm{o}}=5.2 \\
H_{\max }=79.4 \mathrm{~mL} \\
\mathrm{H}_{2} / \mathrm{g}_{\mathrm{VS}}\end{array}$ & $\begin{array}{c}\mathrm{V}_{\mathrm{o}}=1200 \mathrm{~mL} \\
\mathrm{~T}=37{ }^{\circ} \mathrm{C} \\
\mathrm{pH}_{\mathrm{o}}=7.2 \\
b_{\max }=410 \\
\mathrm{~mL} \mathrm{H} \mathrm{H}_{2} / \mathrm{g}_{\mathrm{VS}}\end{array}$ & 14.69 & $\begin{array}{l}\text { Farhat et al. } \\
\text { (2018) }\end{array}$ \\
\hline $\begin{array}{c}\text { Preparation of } \\
\text { FVW:CS } \\
3: 1\end{array}$ & $\begin{array}{c}\text { Acid } \\
\text { hydrolysis } \\
(0.5 \% \mathrm{HCl}, \\
120^{\circ} \mathrm{C}, 120 \\
\text { min })\end{array}$ & Parallel DF and AD & $\begin{array}{c}\mathrm{V}_{\mathrm{o}}=400 \mathrm{~mL} \\
\mathrm{~T}=35^{\circ} \mathrm{C} \\
\mathrm{pH} \mathrm{H}_{\mathrm{o}}=7.0 \\
H_{\max }=223.8 \\
\mathrm{~mL} \mathrm{H}_{2} / \mathrm{g}_{\mathrm{VS}}\end{array}$ & $\begin{array}{c}\mathrm{V}_{\mathrm{o}}=80 \mathrm{~mL} \\
\mathrm{~T}=35^{\circ} \mathrm{C} \\
\mathrm{pH} H_{0}=7.6 \\
b_{\max }=342.3 \\
\mathrm{~mL} \mathrm{CH}_{4} / \mathrm{g}_{\mathrm{VS}}\end{array}$ & 9.7 & This work \\
\hline
\end{tabular}


Abbreviations: $\mathrm{AD}$, anaerobic digestion; $b_{\max }$, Maximum cumulative specific methane production; $\mathrm{DF}$, dark fermentation; 694 $\mathrm{CM}$, cattle manure NA, not applicable; FVW, fruit and vegetable waste; $H_{\max }$, maximum cumulative specific hydrogen production; $\mathrm{OMW}$, olive mill wastewater; $\mathrm{pH}_{0}$, initial $\mathrm{pH}$; $\mathrm{T}$, operational temperature; $\mathrm{V}_{0}$, operational volume; WAS, wasteactivated sludge. 


\section{List of Figures}

Fig. 1 The $h-H-M$ biorefinery concept

Fig. 2 Cumulative specific hydrogen production using LH as substrate

Fig. 3 Anaerobic digestion performance using HS or FVW as substrate in terms of (A) cumulative methane production and (B) cumulative specific methane production 


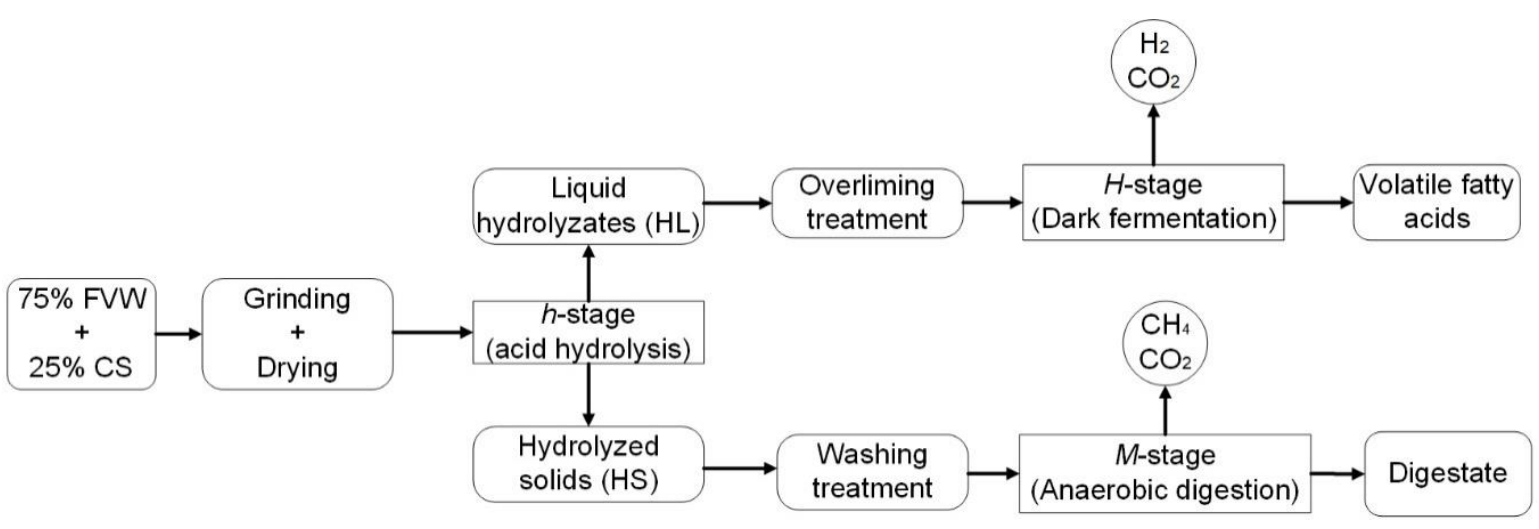

Fig. 1 The $h-H-M$ biorefinery concept 


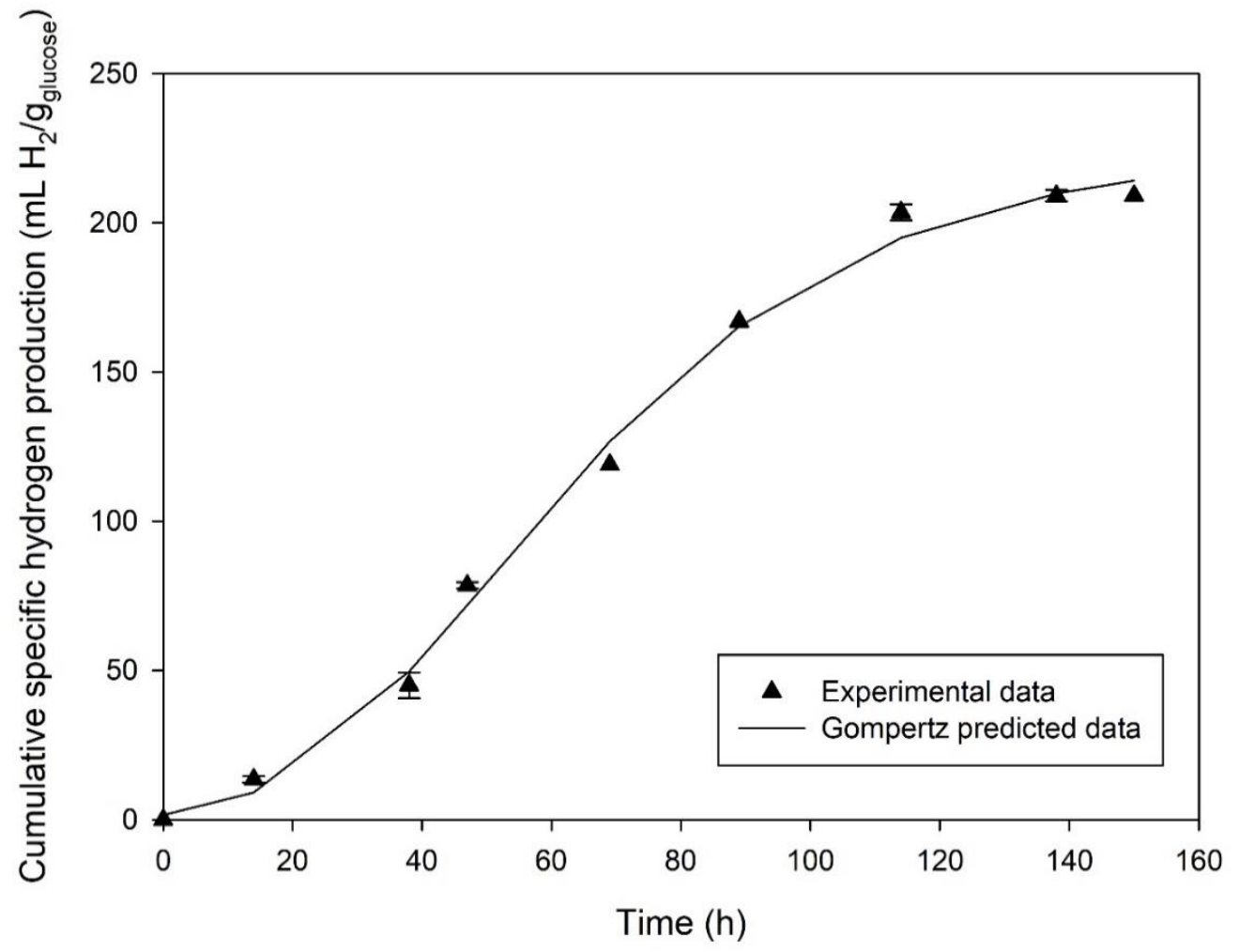

Fig. 2 Cumulative specific hydrogen production using LH as substrate 


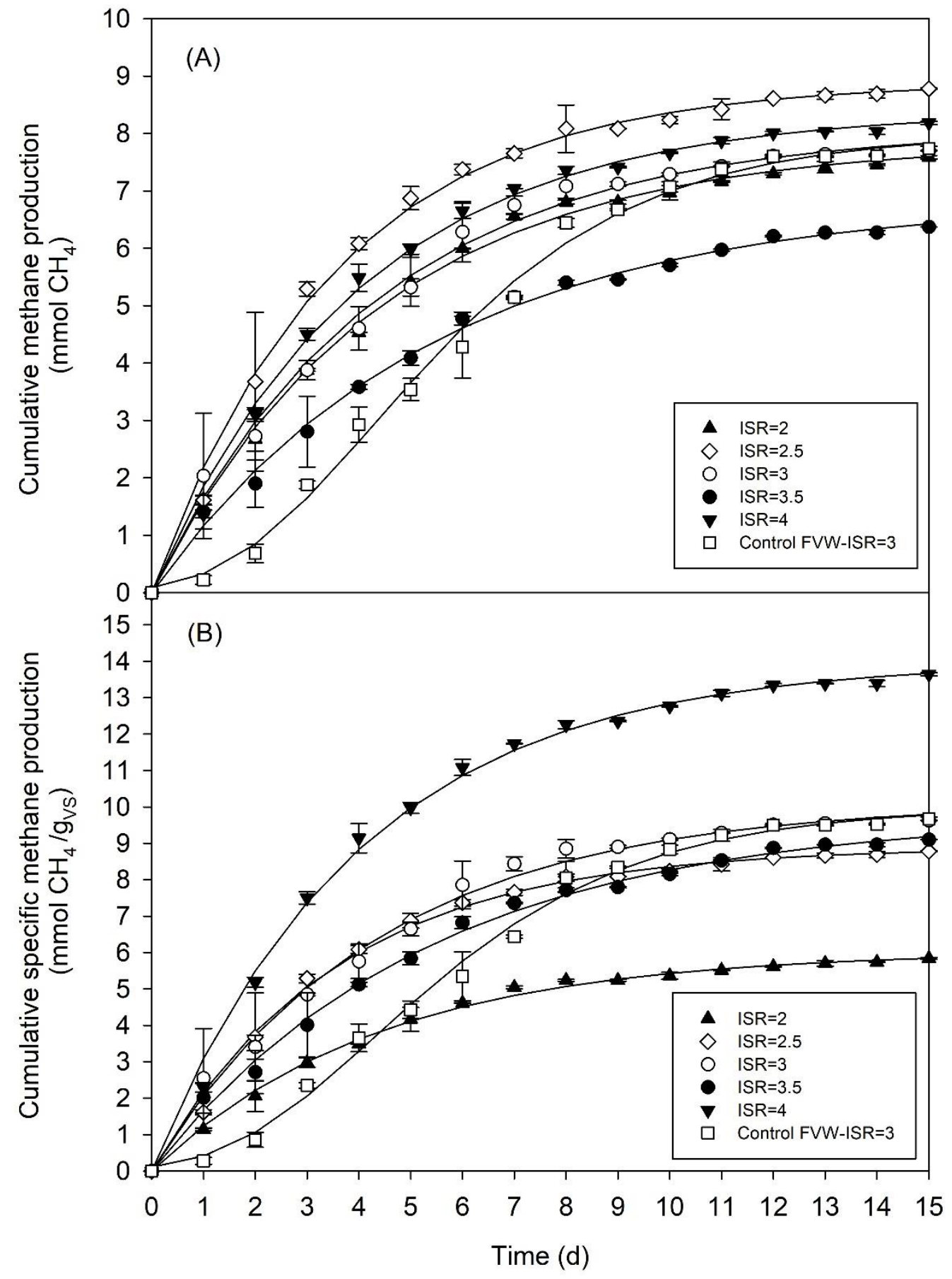

Fig. 3 Anaerobic digestion performance using HS or FVW as substrate in terms of (A) cumulative methane production and (B) cumulative specific methane production

The prediction lines for ISR 2 to 4 correspond to the first order model;

The prediction line for control corresponds to the Gompertz model. 